\title{
Botulinum toxin type-A preparations are not the same medications - clinical studies (Part 2)
}

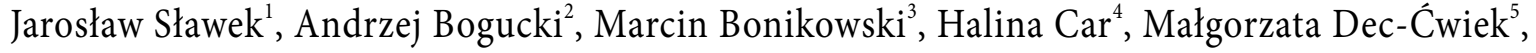 \\ Artur Drużdż ${ }^{6}$ Dariusz Koziorowski ${ }^{7}$, Iwona Sarzyńska-Długosz ${ }^{8}$, Monika Rudzińska ${ }^{9}$ \\ ${ }^{1}$ Division of Neurological and Psychiatric Nursing, Faculty of Health Sciences, Medical University of Gdansk, Poland;
}

Department of Neurology and Stroke, St. Adalbert Hospital, Gdansk, Poland

${ }^{2}$ Department of Extrapyramidal Disorders, Medical University of Łodz, Poland

${ }^{3}$ Mazovian Neuropsychiatry Centre, Limited Liability Company, Neuro Rehabilitation Department,

Movement Analysis Laboratory, Zagorze, Poland

${ }^{4}$ Department of Experimental Pharmacology, Medical University of Bialystok, Poland

${ }^{5}$ Department of Neurology, Jagiellonian University Medical College, Krakow, Poland

${ }^{6}$ Department of Neurology, Municipal Hospital in Poznan, Poland

${ }^{7}$ Department of Neurology, Faculty of Heath Science, Medical University of Warsaw, Poland

${ }^{8}$ Second Department of Neurology, Neurorehabilitation Ward, Institute of Psychiatry and Neurology, Warsaw, Poland

${ }^{9}$ Department of Neurology, Faculty of Medicine and Health Sciences. Andrzej Frycz Modrzewski Krakow University, Krakow, Poland

\begin{abstract}
The growing number of botulinum neurotoxin type-A (BoNT/A) preparations on the market has resulted in a search for pharmacological, clinical and pharmacoeconomic differences. Patients are occasionally switched from one botulinum toxin formulation to another.

The aim of this paper was to review studies that have made direct comparisons of the three major BoNT/A preparations presently on the market: ona-, abo- and incobotulinumtoxinA. We also review the single medication Class I pivotal and occasionally Class II-IV studies, as well as recommendations and guidelines to show how effective doses have been adopted in well-established indications such as blepharospasm, hemifacial spasm, cervical dystonia and adult spasticity.

Neither direct head-to-head studies nor single medication studies between all preparations allow the formation of universal conversion ratios. All preparations should be treated as distinct medications with respect to their summary of product characteristics when used in everyday practice.
\end{abstract}

Key words: botulinum toxin type-A, cervical dystonia, blepharospasm, spasticity, hemifacial spasm

(Neurol Neurochir Pol 2021; 55 (2): 141-157)

\section{Introduction}

Currently, there are three commercially available botulinum neurotoxin type-A (BoNT/A) preparations available, widely used and licensed in a majority of countries: onabotulinumtoxinA (ONA-BoNT/A, Botox); abobotulinumtoxinA (ABO-BoNT/A, Dysport); and incobotulinumtoxinA (INCOBoNT/A, Xeomin).
They have similar mechanisms of action. However, their chemical formulations, clinical potency, dosing and safety profiles are different. This can result in bio- and pharmacoeconomical equivalence problems. The discussion on bioequivalence and switching from one to another preparation is still ongoing $[1,2]$. This discussion will certainly be continued in future as new preparations (e.g. daxibotulinumtoxinA, prabotulinumtoxinA) are now in clinical trials.

Address for correspondence: Jarosław Sławek, MD, PhD, Department of Neurology and Stroke, St. Adalbert Hospital, Al. Jana Pawła II 50 Str., $80-462$ Gdansk, Poland, e-mail: jaroslaw.slawek@gumed.edu.pl 
Table 1. Selected studies on BoNT/A in treatment of blepharospasm and hemifacial spasm (dose ratio comparison between different products)

\begin{tabular}{|c|c|c|c|c|c|}
\hline Reference & Study design & $\begin{array}{l}\text { Patient characteristics } \\
\text { and outcome }\end{array}$ & $\begin{array}{l}\text { BoNT/A and dose } \\
\text { (U) }\end{array}$ & $\begin{array}{l}\text { Muscle injected/ } \\
\text { /injection guide }\end{array}$ & $\begin{array}{l}\text { Efficacy outcome/ } \\
\text { /adverse events }\end{array}$ \\
\hline $\begin{array}{l}\text { Nussgens et al. } \\
1997 \text { [9] }\end{array}$ & $\begin{array}{l}\text { Class II study } \\
\text { DB, prospective, } \\
\text { crossover design; com- } \\
\text { parison of ONA- and } \\
\text { ABO-BoNT/A }\end{array}$ & $\begin{array}{l}n=212 B S \\
\text { Duration of effect }\end{array}$ & $\begin{array}{l}\text { ONA-BoNT/A } \\
\text { Mean dose } 44 \mathrm{U} \\
\text { ABO-BoNT/A } \\
\text { Mean dose } 182 \mathrm{U} \\
\text { Mean ratio: } 1: 4\end{array}$ & $\begin{array}{l}\text { Orbicularis oculi } \\
\text { muscle }\end{array}$ & $\begin{array}{l}\text { AEs: } \\
\text { ONA-BoNT/A: 17\%; } \\
\text { ABO-BoNT/A: 24\%; } \\
\text { Ptosis (less with ONA- } \\
\text {-BoNT/A) }\end{array}$ \\
\hline $\begin{array}{l}\text { Sampaio et al. } \\
1997[8]\end{array}$ & $\begin{array}{l}\text { Prospective } \\
\text { randomised study: } \\
\text { a single-blind, } \\
\text { randomised, parallel } \\
\text { comparison }\end{array}$ & $\mathrm{n}=91$ with $\mathrm{BS}$ or HFS & $\begin{array}{l}\text { ONA-BoNT/A or } \\
\text { ABO-BoNT/A pre-esti- } \\
\text { mated ratio: } 1: 4\end{array}$ & $\begin{array}{l}\text { Orbicularis oculi } \\
\text { muscle }\end{array}$ & $\begin{array}{l}\text { Similar duration of effect: } \\
13.3+/-5.9 \text { weeks for } \\
\text { ABO-BoNT/A, and } 11.2 \\
+/-5.8 \text { for ONA-BoNT/A. } \\
\text { Adverse events noted in } \\
50 \% \text { of both }\end{array}$ \\
\hline $\begin{array}{l}\text { Roggenkamper } \\
\text { et al. } 2006 \text { [14] }\end{array}$ & $\begin{array}{l}\text { Class I study } \\
\text { DB, randomised, } \\
\text { prospective, parallel } \\
\text { design; comparison } \\
\text { of ONA-BoNT/A and } \\
\text { INCO-BoNT/A }\end{array}$ & $\begin{array}{l}n=300 \text { BS adjusted mean } \\
\text { change in JRS, BDI at weeks } \\
3,16 \\
\text { Duration of effect }\end{array}$ & $\begin{array}{l}\text { ONA -BoNT/A Mean } \\
\text { dose } 40.8 \mathrm{U} \\
\text { INCO-BoNT/A Mean } \\
\text { dose } 39.6 \mathrm{U} \\
\text { Mean ratio: 1:1 }\end{array}$ & $\begin{array}{l}\text { Orbicularis oculi } \\
\text { muscle }\end{array}$ & $\begin{array}{l}\text { Efficacy, AEs, duration: } \\
\text { similar for both }\end{array}$ \\
\hline $\begin{array}{l}\text { Wabbels et al. } \\
2011 \text { [16] }\end{array}$ & $\begin{array}{l}\text { Class I, DB, randomised, } \\
\text { prospective, parallel } \\
\text { design; comparison } \\
\text { of ONA-BoNT/A and } \\
\text { INCO-BoNT/A }\end{array}$ & $\begin{array}{l}\mathrm{n}=65 \mathrm{BS} \\
\text { Change in BDI at weeks } 4 \\
\text { and } 8 ; \\
\text { Change in JRS; } \\
\text { Change in patient global } \\
\text { assessment at week } 4\end{array}$ & $\begin{array}{l}\text { ONA-BoNT/A: Mean } \\
\text { dose } 29 \text { U/eye; } \\
\text { INCO-BoNT/A: Mean } \\
\text { dose } 27 \text { U/eye } \\
\text { Mean ratio: } 1: 1\end{array}$ & $\begin{array}{l}\text { Orbicularis oculi } \\
\text { muscle }\end{array}$ & $\begin{array}{l}\text { Similar efficacy and dura- } \\
\text { tion for both }\end{array}$ \\
\hline $\begin{array}{l}\text { Saad and Gour- } \\
\text { deau } 2014 \text { [15] }\end{array}$ & $\begin{array}{l}\text { Class II } \\
\text { DB, randomised, split- } \\
\text { face design; } \\
\text { comparison of ONA- } \\
\text { BoNT/A and } \\
\text { INCO-BoNT/A }\end{array}$ & $\begin{array}{l}n=48 \text { BS } \\
4 \text { consecutive treatments } \\
\text { JRS, BDI score at each visit. } \\
\text { Likert scale for Orbicularis } \\
\text { oculi strength at each visit. } \\
\text { Likert scale for spasm } \\
\text { severity at each visit. } \\
\text { Patient preference }\end{array}$ & $\begin{array}{l}\text { ONA-BoNT/A or } \\
\text { INCO-BoNT/A } \\
\text { mean dose } 19.9 \mathrm{U} / \\
\text { eye. } \\
\text { Mean ratio: 1:1 }\end{array}$ & $\begin{array}{l}\text { Orbicularis oculi } \\
\text { muscle }\end{array}$ & $\begin{array}{l}\text { Similar effects. } \\
\text { AEs: not available }\end{array}$ \\
\hline $\begin{array}{l}\text { Grosset et al. } \\
2015 \text { [19] }\end{array}$ & $\begin{array}{l}\text { Open study } \\
\text { comparison of } \\
\text { ABO-BoNT/A and } \\
\text { INCO-BoNT/A }\end{array}$ & $\begin{array}{l}n=19 \text { BS } \\
n=91 \text { HFS } \\
4 \text { consecutive treatments } \\
\text { Patient assessment } \\
\text { of treatment efficacy } \\
\text { (7-point scale comprising } \\
\text { excellent, very good, good, } \\
\text { fairly good, fair, poor, or } \\
\text { negligible) and duration of } \\
\text { treatment effect (a 4-point } \\
\text { scale comprising excellent, } \\
\text { good, a few weeks, or } \\
\text { short-lived) }\end{array}$ & $\begin{array}{l}\text { ABO -BoNT/A: } \\
\text { Mean dose } \\
\text { BS } 80 \mathrm{U} \\
\text { HFS } 46 \mathrm{U} \text {. } \\
\text { INCO-BoNT/A: } \\
\text { Mean dose } \\
\text { BS } 20 \mathrm{U} \\
\text { HFS } 11 \mathrm{U} \text {. } \\
\text { Mean ratio: 4:1 }\end{array}$ & $\begin{array}{l}\text { Orbicularis oculi } \\
\text { muscle }\end{array}$ & Similar duration of effect \\
\hline $\begin{array}{l}\text { Kollewe et al. } \\
2015 \text { [20] }\end{array}$ & Open study & $\begin{array}{l}n=288 \mathrm{BS} \\
8 \text { consecutive treatments } \\
\mathrm{GCl}\end{array}$ & $\begin{array}{l}\text { Mean doses: } \\
\text { ONA-BoNT/A } \\
47.1 \mathrm{U} \text {; } \\
\text { INCO-BoNT/A } \\
62.11 \mathrm{U} \text {; } \\
\text { ABO-BoNT/A } \\
\text { 120.35 U. } \\
\text { Mean ratios: } \\
\text { ONA-BoNT/A to } \\
\text { ABO-BoNT/A } \\
\text { 1:2.3 } \\
\text { ONA-BoNT/A to } \\
\text { INCO-BoNT/A } \\
\text { 1:1.2 } \\
\text { INCO-BoNT/A to } \\
\text { ABO-BoNT/A } \\
\text { 1:2.0 }\end{array}$ & $\begin{array}{l}\text { Orbicularis oculi } \\
\text { muscle } \\
3-4 \text { site injections }\end{array}$ & $\begin{array}{l}\text { Similar effects and AEs in } \\
\text { all three }\end{array}$ \\
\hline
\end{tabular}

ABO-A — abobotulinumtoxinA; $\mathrm{AE}$ - adverse event; BDI - Blepharospasm Disability Index; BDS - Blepharospasm Disability Scale; BoNT — botulinum neurotoxin; $\mathrm{Cl}$ - confidence interval; DB - double-blind; INCO-A — incobotulinumtoxinA; JRS — Jankovic Rating Scale; ONA-A — onabotulinumtoxinA; PBO — placebo; PC — placebo-controlled; U — unit(s) 
In Part 1 of this discussion, we presented the basic pharmacological differences between all three preparations [3]. Here in Part 2, the same group of authors provide a summary of product characteristics (SPC) and review the available clinical studies on major neurological indications (i.e. blepharospasm, BS; hemifacial spasm, HFS; cervical dystonia, CD; and upper and lower limb spasticity, ULS, LLS in adults), comparing all three BoNT/A preparations in terms of their bioequivalence, which is understood as clinical effectiveness, dosing and safety. Guidelines and recommendations are also included. We have prioritised randomised, double-blind studies, those directly comparing different preparations of BoNT/A, but where these are lacking we have also looked at Class II-IV studies. We review also single medication studies to make indirect comparisons for the same indication.

\section{Blepharospasm and hemifacial spasm}

BoNT/A is considered to be the first line treatment of BS and HFS, but only a few studies have been published comparing the different preparations. According to SPC, ONABoNT/A and INCO-BoNT/A are injected into the medial and lateral orbicularis oculi of the upper lid and the lateral orbicularis oculi of the lower lid. The initial recommended dose is $1.25-2.5 \mathrm{U}$ at each site, and it should not exceed $25 \mathrm{U}$ per eye. At subsequent treatment sessions, the dose may be increased up to two-fold if the response to the initial treatments is considered insufficient. In the management of $\mathrm{BS}$, the dose should not exceed $100 \mathrm{U}$ in total every 12 weeks. $\mathrm{ABO}-\mathrm{BoNT} / \mathrm{A}$ is injected in an initial dose of $40 \mathrm{U}$ per eye. The injection site should be localised into the junction between the preseptal and orbital parts of both the upper and lower orbicularis oculi muscles of each eye $10 \mathrm{U}$ medially and $10 \mathrm{U}$ into four sites. If the response to initial treatment is inadequate, it may be necessary to increase the dose at subsequent visits up to $60 \mathrm{U}, 80 \mathrm{U}$ or even $120 \mathrm{U}$. In the management of BS and HFS, the total dose should not exceed $120 \mathrm{U}$ per eye every 12 weeks [4-6].

We set out the short characteristics of comparative studies in Table 1. Single medication studies are shown in Table 2.

\section{ONA-BoNT/A vs. ABO-BoNT/A}

The first study comparing different types of BoNT/A was published more than 25 years ago. In the 1995 study by Marion et al., 111 patients with BS and HFS with a good response to ABO-BoNT/A over at least 12 months of treatment were switched to ONA-BoNT/A with dose ratio 3:1, obtaining similar effects [7]. Two other double-blind studies included $300 \mathrm{pa}-$ tients with both BS and HFS and compared ONA-BoNT/A to $\mathrm{ABO}-\mathrm{BoNT} / \mathrm{A}$. The authors did not observe any difference in clinical efficacy of effect duration at a dose ratio of 1:4 [8,9]. Bihari (2005) in a cross-over prospective, open label study in a group of 27 patients with BS and nine patients with HFS, confirmed the same efficacy of both products at a dose ratio of
1:4-1:5 [10]. A retrospective study by Marchetti et al. (2005) published the results of 114 patients with BS who received for at least 12 months ONA-BoNT/A (mean dose $33 \pm 12 \mathrm{U}$ ) before switching to ABO-BoNT/A (mean dose $147 \pm 58 \mathrm{U}$ ), or conversely started with ABO-BoNT/A (mean dose 125 $\pm 49 \mathrm{U}$ ) before switching to ONA-BoNT/A (mean dose $31 \pm 10 \mathrm{U}$ ) with treatment continuing for one year. The ratio of mean dose of ONA-BoNT/A and ABO-BoNT/A ranged from a low of 1:2 up to a high of 1:11 (mean 1:3 to 1:4) [11]. Bentivoglio et al. (2012) compared the pairs of treatments with a switch from one brand to another (ONA-BoNT/A and ABO-BoNT/A) in the same patient ( $n=46$ with BS and $n=31$ with HFS) in consecutive sessions with overlapping clinical outcomes, and found ratios to be highly variable (range: 1:1.2-13.3). In most cases (65\%), it was between 1:3 and 1:5 [12].

\section{ONA-BoNT/A vs. INCO-BoNT/A}

Dressler et al. (2009) published the results of a prospective study comparing ONA-BoNT/A to INCO-BoNT/A in a group of patients with different disorders. Two hundred and sixty-three patients (including 12 with BS and 17 with HFS) who had been previously treated with ONA-BoNT/A for at least 12 months under stable conditions were converted, in a blinded fashion, to INCO-BoNT/A using a 1:1 conversion ratio and with other treatment parameters identical. Patients with BS received a mean total dose of $85.1 \pm 32.6 \mathrm{U}$ ONA- and INCO-BoNT/A and patients with HFS received $44.7 \pm 19.5 \mathrm{U}$. There were no subjective or objective differences between both products with respect to onset latency, maximum duration of therapeutic effect, or adverse effects [13]. The same 1:1 ratio was confirmed by two other studies $[14,15]$.

Wabbels et al. found that ONA-BoNT/A vs. INCOBoNT/A (mean dose 29 U/eye and 27 U/eye respectively) had comparable magnitude and duration of benefit (13 weeks). However, a post hoc analysis showed a significantly greater number of ONA-BoNT/A treated patients reaching a responder threshold of 4 points on the total score of disability [14]. Other studies have shown that patients with BS and HFS who were treated with INCO-BoNT/A had a significantly shorter treatment interval (10.2 weeks vs. 13.0 weeks) or required a higher average dose compared to ONA-BoNT/A $[2,15,16]$.

Similar results were confirmed in the TRUEDOSE Pilot Study. The objective was a retrospective evaluation of the dose utilisation of ONA-BoNT/A and INCO-BoNT/A in 14 BS patients treated over four years. Patients were switched from ONA- (mean dose 14.41 U per eye) to INCO-BoNT/A (mean dose $17.09 \mathrm{U}$ ). For BS, the average annual dose per patient year for ONA-BoNT/A was $50.4 \pm 50.6 \mathrm{U}$, and significantly lower $v s$. INCO-BoNT/A with an average dose of $64.01 \pm$ $53.2 \mathrm{U}(\mathrm{p}=0.002)$. Average total dose ratio (mean dose/year) was $1: 1.27$. The inter-injection intervals were significantly longer (16.25 vs. 14.24 weeks) for ONA- than for INCOBoNT/A $(\mathrm{p}=0.04)[2]$. 
Table 2. Selected studies on BoNT/A in treatment of blepharospasm and hemifacial spasm (single toxin, indirect comparisons possible only)

\begin{tabular}{|c|c|c|c|c|c|}
\hline References & Study design & $\begin{array}{l}\text { Patients characteristics } \\
\text { and outcome measures }\end{array}$ & $\begin{array}{l}\text { BoNT/A and dose } \\
\text { (U) }\end{array}$ & $\begin{array}{l}\text { Muscles } \\
\text { injected }\end{array}$ & $\begin{array}{l}\text { Efficacy outcomefadverse } \\
\text { events }\end{array}$ \\
\hline $\begin{array}{l}\text { Jankovic and } \\
\text { Orman } 1987 \\
{[21]}\end{array}$ & $\begin{array}{l}\text { Class II study } \\
\text { blinded, prospective, } \\
\text { crossover design }\end{array}$ & $\begin{array}{l}\mathrm{n}=12 \mathrm{BS} \\
\text { Fahn scale and patient } \\
\text { subjective scale }\end{array}$ & $\begin{array}{l}\text { ONA-BoNT/A } \\
25 \text { U/eye, if ineffective } \\
\text { then } 50 \text { U/eye }\end{array}$ & $\begin{array}{l}\text { Orbicularis oculi } \\
\text { muscle }\end{array}$ & $\begin{array}{l}\text { Improvement, } A E s \text {, reported } \\
\text { but no percentage numbers } \\
\text { reported }\end{array}$ \\
\hline $\begin{array}{l}\text { Yoshimura et al. } \\
1992 \text { [22] }\end{array}$ & $\begin{array}{l}\text { Randomised, double } \\
\text { blind } \\
\text { crossover design }\end{array}$ & $\begin{array}{l}\mathrm{n}=11 \mathrm{HFS} \\
\text { Subjective improvement; } \\
\text { analogue 10-point scale. } \\
\text { Objective improvement } \\
\text { (blinded review of } \\
\text { videotapes made one } \\
\text { month after each injection) } \\
\text { assessed with categorical } \\
\text { 10-point scale }\end{array}$ & $\begin{array}{l}\text { ONA-BoNT/A } \\
\text { three different doses } \\
\text { compared to placebo } \\
\text { Total dose } \\
5-90 \mathrm{U}\end{array}$ & $\begin{array}{l}\text { Selection of } \\
\text { muscles to inject } \\
\text { were based on } \\
\text { clinical exami- } \\
\text { nation }\end{array}$ & $\begin{array}{l}\text { Subjective improvement after } \\
79 \% \text { of injections. } \\
\text { Objective improvement after } \\
84 \% \text { of injections. } \\
\text { AEs: facial weakness }(97 \%) \text {, facial } \\
\text { bruising }(20 \%), \\
\text { diplopia ( } 13 \%), \text { ptosis }(7 \%)\end{array}$ \\
\hline $\begin{array}{l}\text { Girlanda et al. } \\
1996 \text { [23] }\end{array}$ & $\begin{array}{l}\text { Class II study } \\
\text { comparing two eyes } \\
\text { of same patient with } \\
\text { normal saline control }\end{array}$ & $\begin{array}{l}n=6 \text { BS } \\
\text { Subjective scale in blinded } \\
\text { video rating }\end{array}$ & $\begin{array}{l}\text { ONA-BoNT/A } \\
20 \text { U/eye } \\
\text { or } \\
\text { normal saline }\end{array}$ & $\begin{array}{l}\text { Orbicularis oculi } \\
\text { muscle }\end{array}$ & $\begin{array}{l}\text { Reduction in blepharospasm } \\
\text { AEs: not available }\end{array}$ \\
\hline $\begin{array}{l}\text { Truong et al. } \\
2008[24]\end{array}$ & $\begin{array}{l}\text { Class II study, } \\
\text { DB, randomised, paral- } \\
\text { lel group, PC }\end{array}$ & $\begin{array}{l}n=123 \text { BS } \\
\text { Primary measure: differ- } \\
\text { ence in BDS }\end{array}$ & $\begin{array}{l}\text { ABO-BoNT/A } \\
40 \mathrm{U}, 80 \mathrm{U} \text {, or } 120 \mathrm{U} \\
\text { per eye }\end{array}$ & $\begin{array}{l}\text { Orbicularis oculi } \\
\text { muscle }\end{array}$ & $\begin{array}{l}\text { Disability improved in dose-re- } \\
\text { lated manner. } \\
\text { AEs: } \\
\text { ptosis (13-39-58\%), blurred } \\
\text { vision (23-19-42\%), diplopia (10- } \\
16-16 \%) \text { for doses } 40-80-120 \mathrm{U} \\
\text { respectively } \\
\text { Comments: } \\
80 \text { U/eye preferred as efficacious } \\
\text { and safe. High number of } \\
\text { withdrawals. } 35 \% \text { of PBO group } \\
\text { completed study }\end{array}$ \\
\hline $\begin{array}{l}\text { Jankovic et al. } \\
2011[25]\end{array}$ & $\begin{array}{l}\text { Class I, DB, randomised, } \\
\text { prospective, parallel } \\
\text { design; randomised 2:1 } \\
\text { to INCO-BoNT/A } \\
\text { vs. PBO }\end{array}$ & $\begin{array}{l}n=109 \text { BS } \\
\text { JRS, BDI score at weeks 3, } 6 \\
\text { and end of study. } \\
\text { Time for need for new } \\
\text { injection on basis of JRS } \\
\text { score }>2 \text {, up to } 20 \text { weeks } \\
\text { investigator global assess- } \\
\text { ment }\end{array}$ & $\begin{array}{l}\text { INCO-BoNT/A up to } \\
50 \text { U/eye }\end{array}$ & $\begin{array}{l}\text { Orbicularis oculi } \\
\text { muscle }\end{array}$ & $\begin{array}{l}\text { Statistically significant improve- } \\
\text { ment. } \\
\text { AEs: } \\
\text { ptosis (18.9\%), dry eye }(18.9 \%)\end{array}$ \\
\hline
\end{tabular}

ABO-A - abobotulinumtoxinA; AEs - adverse events; BDI - Blepharospasm Disability Index; BDS - Blepharospasm Disability Scale; BoNT - botulinum neurotoxin; $\mathrm{Cl}$ - confidence interval; DB - double-blind; INCO-A — incobotulinumtoxinA; JRS — Jankovic Rating Scale; ONA-A — onabotulinumtoxinA; PBO — placebo; PC — placebo-controlled; U — unit(s)

\section{ABO-BoNT/A vs. INCO-BoNT/A}

Grosset et al. in a retrospective 12-month study assessed dose equivalence ratio between $\mathrm{ABO}-\mathrm{BoNT} / \mathrm{A}$ and INCOBoNT/A in a group of 257 cases including 19 patients with BS and 91 with HFS. Patients were switched from ABO- (mean dose for BS $89 \mathrm{U}$ and for HFS $46 \mathrm{U}$ ) to INCO-BoNT/A and observed for at least one year. Switching from ABO-BoNT/A to INCO-BoNT/A at a 4:1 unit ratio resulted in good therapeutic effectiveness in terms of treatment efficacy, duration of treatment effect, and adverse events profile [17].

\section{ONA-BoNT/A vs. INCO-BoNT/A vs. ABO-BoNT-A}

Kollewe et al. published the first study comparing the efficacy and adverse effects of all three major BoNT/A preparations over a treatment time of $11.2 \pm 4.1$ years. Two hundred and eighty-eight patients with BS were included and $85 \%$ were treated with a stable dose: 128 patients with ONA-BoNT/A (mean dose $47 \pm 10 \mathrm{U}), 84$ patients with ABO-BoNT/A (mean dose $120 \pm 35 \mathrm{U}$ ), and 76 patients with INCO-BoNT/A (mean dose $62 \pm 11 \mathrm{U}$ ). No patient was switched between preparations throughout the observation period. The Clinical Global Improvement Scale score $(2.5 \pm 0.6)$ and adverse effects frequency $(3 \%)$ were similar in all compared preparations. ONA-BoNT/A doses were $16.7 \%$ lower than INCO-BoNT/A ( $<<0.001)$, and the dose ratio between them was calculated as 1:1.2. Dose ratios between ONA- and ABO-BoNT/A was 1:2.3; between INCO- and ABO-BoNT/A it was 1:2.0. Therapeutic effects started after 6.1 days and lasted for 10 weeks and were not significantly different between all three products [18]. Papers including direct comparisons between preparations are set out in Table 1. 


\section{Conclusions}

- The range of conversion ratios between all three products extracted from all studies was wide: ONA- $v s$. INCO-BoNT/A from 1:1 to 1:1.27, and between ONA- and ABO-BoNT/A from 1:3 to 1:5

- The number of adverse effects is similar in most studies, but duration was slightly longer in ABO- $v s$. ONA- and ONA- vs. INCO-BoNT/A

- Based on a SPC, and having reviewed studies on the efficacy and safety of BS and HFS treatment, making comparisons between the available preparations remains difficult. This is due to the small number of Class I and II trials, differing study designs (sometimes with adopted conversion rate) and assessment scales used in these studies (VAS, Jankovic scale, blepharospasm disability scale), and differing sites of injections (pretarsal or preseptal region). We believe this results in an inability to establish a fixed conversion factor

- Dosing should be based on individual patient need according to the recommendation of the SPC for each BoNT/A preparation.

\section{Cervical dystonia (CD)}

Due to the insufficient effects of oral pharmacological treatment of CD, BoNT/A is currently considered to be the first line therapy. According to the SPC, it is recommended that for ONA-BoNT/A a maximal dose of $200 \mathrm{U}$ should be administered initially, and the dose should not exceed $300 \mathrm{U}$ in subsequent treatment sessions [4]. There is a similar recommendation for INCO-BoNT/A [6]. For ABO-BoNT/A, the recommended starting dose is $500 \mathrm{U}$. As treatment is continued, the doses may be appropriately adjusted according to the treatment effects and observed side effects (e.g. dysphagia). However, the maximum dose administered must not exceed $1,000 \mathrm{U}[5]$.

We set out selected comparative (direct comparison) studies in Table 3 and single medication studies (indirect comparison) in Table 4.

\section{Comparative studies}

There is still little data on direct comparisons of individual toxin preparations in $\mathrm{CD}$ patients. Studies have compared mainly ONA- vs. ABO- and INCO-BoNT/A preparations and were aimed at comparing the effectiveness or side effects, searching for a conversion ratio.

\section{ONA-BoNT/A vs. ABO-BoNT/A}

Odergren et al. included 73 patients in a randomised trial comparing ONA- and ABO-BoNT/A, who had previously been treated with BoNT/A with good results. They adopted a fixed 1:3 ratio between products and obtained a similar duration, number of side effects, and overall Tsui scale improvement [26].
A similar approach was applied by Ranoux et al. in a crossover study comparing ONA- and ABO-BoNT/A with pre-fixed conversion factors of 1:3 and 1:4. The study included patients treated successfully at least twice with ONA-BoNT/A. Each patient was subjected to three cycles of therapy. ABO-BoNT/A efficacy was significantly higher for both conversion ratios (Tsui scale, pain scale), and the effect lasted longer. However, in patients receiving ABO-BoNT/A, adverse events (mostly dysphagia) were twice as frequent regardless of the dose ratio [27].

The aim of the study conducted by Marchetti et al. was to evaluate the real-world dose utilisation of ONA- and ABO-BoNT/A for CD and BS. They abstracted utilisation data for patients who received ABO- before switching to ONA-BoNT/A, or conversely. Patients were identified during scheduled clinic visits and selected if they met the study criteria, which included treatment for at least two consecutive years (at least one year with ABO- or ONA-BoNT/A, then switched and maintained on one of them for at least another year, adjusting the dose to achieve a similar effect). A total of 114 patients were included in the assessment. Ratios of mean dose for ABO- to ONA-BoNT/A ranged from a low of 2:1 to a high of 11:1. Thirty-one percent of patients fell into the ABO- to ONA-BoNT/A ratio group of $5: 1$ to less than $6: 1 ; 30 \%$ with a ratio of $4: 1$ to less than $5: 1$; and only $21 \%$ was in a range of $3: 1$ to less than $4: 1$ [11].

A double-blind, randomised crossover trial by Rystedt et al. compared ONA-BoNT/A and ABO-BoNT/A in two different dose conversion ratios (1:3 and 1:1.7) when diluted to the same concentration $(100 \mathrm{U} / \mathrm{mL})$. Forty-six patients received three different treatments: ONA- in two different doses and ABO-BoNT/A as a control treatment. Efficacy was evaluated four and 12 weeks after treatment using, among others, Toronto Western Spasmodic Torticollis Rating Scale (TWSTRS); no differences were observed. At week 12 , a statistically significant difference in effect between ONA-BoNT/A (1:3) and $\mathrm{ABO}-\mathrm{BoNT} / \mathrm{A}$ was noticed, suggesting a shorter duration of effect for ONA-BoNT/A. This study showed that the ratio of 1:3 resulted in suboptimal efficacy of Botox, and indicates that the dose conversion ratio between ONA-BoNT/A $100 \mathrm{U} / \mathrm{mL}$ and $\mathrm{ABO}-\mathrm{BoNT} / \mathrm{A} 100 \mathrm{U} / \mathrm{mL}$ may be lower than 1:3, but this needs to be validated in a larger study [28].

In a randomised, double-blind, multicentre, non-inferiority, two-period crossover study performed by Yun et al., patients were randomly assigned to initial treatment with $\mathrm{ABO}$ - or ONA-BoNT/A, and they were followed up for 16 weeks after the injection. After a 4-week washout period, they were switched to the other formulation and followed up for another 16 weeks. The primary outcome was the change in the Tsui scale between the baseline and week 4 after each injection. Mean changes in the Tsui scale between baseline and 4 weeks after each injection tended to favour ONA-BoNT/A; however, this was not statistically significant $(4.0 \pm 3.9$ points for the ABO- treatment $v s .4 .8 \pm 4.1$ points for ONA-BoNT/A; $\mathrm{p}=0.091)$. The mean changes in the Tsui scale, TWSTRS, the 
Table. 3. Selected studies on BoNT/A in treatment of cervical dystonia (dose ratio comparison between different products)

\begin{tabular}{|c|c|c|c|c|c|}
\hline $\begin{array}{l}\text { Referen- } \\
\text { ces }\end{array}$ & Study design & $\begin{array}{l}\text { Patients characteri- } \\
\text { stics and outcome }\end{array}$ & $\begin{array}{l}\text { BoNT/A and dose } \\
\text { (U) }\end{array}$ & $\begin{array}{l}\text { Muscles injected/ } \\
\text { /injection guide }\end{array}$ & $\begin{array}{l}\text { Efficacy outcome/ } \\
\text { /adverse events }\end{array}$ \\
\hline $\begin{array}{l}\text { Odergren } \\
\text { et al. } 1998 \\
{[26]}\end{array}$ & $\begin{array}{l}\mathrm{RCT}, \mathrm{DB} \text {, parallel group, } \\
\text { prospective multicentre } \\
\text { study, comparison of } \\
\text { ONA- and ABO-BoNT/A }\end{array}$ & $\begin{array}{l}\mathrm{n}=73 \\
\text { Patients with a minimum } \\
\text { of four previous ONA- } \\
\text {-BoNT/A treatments, } \\
\text { randomised to receive } \\
\text { either clinically indicated } \\
\text { dose of ONA-BoNT/A or } \\
\text { ABO-BoNT/A with fixed } \\
\text { ratio 1:3 } \\
\text { Tsui scores, duration, } \\
\text { adverse events }\end{array}$ & $\begin{array}{l}\text { ABO-BoNT/A mean } \\
\text { dose of } 477 \mathrm{U} \text { (range } \\
240-720) \\
\text { ONA-BoNT/A mean } \\
\text { dose of 152U (range } \\
70-240)\end{array}$ & $\begin{array}{l}\text { Anatomical landmarks, multi- } \\
\text { ple injections within muscles } \\
\text { allowed }\end{array}$ & $\begin{array}{l}\text { Tsui score, similar effect } \\
\text { at week } 4 \\
\text { (ABO-BoNT/A, 49\%, } \\
\text { ONA-BoNT/A, 44\%) } \\
\text { Similar duration: } \\
\text { ABO-BoNT/A mean } 83.9 \\
\text { days } \\
\text { ONA-BoNT/A mean } 80.7 \\
\text { days } \\
\text { Similar number of AEs }\end{array}$ \\
\hline $\begin{array}{l}\text { Ranoux } \\
\text { et al. } 2002 \\
{[27]}\end{array}$ & $\begin{array}{l}\mathrm{RCT}, \mathrm{DB} \text {, three cycles } \\
\text { crossover study }\end{array}$ & $\begin{array}{l}\mathrm{n}=54 \\
\text { Tsui scores, TWSTRS pain } \\
\text { scores, duration, adverse } \\
\text { events }\end{array}$ & $\begin{array}{l}\text { Effective dose of } \\
\text { ONA-BoNT/A was } \\
\text { changed to ABO- } \\
\text {-BoNT/A at fixed } \\
\text { ratio } 1: 3 \text { or } 1: 4\end{array}$ & $\begin{array}{l}\text { Anatomical landmarks. All } \\
\text { injections performed by } \\
\text { same neurologist blinded to } \\
\text { treatment and using same } \\
\text { technique: one single injec- } \\
\text { tion point per muscle, close } \\
\text { to motor point }\end{array}$ & $\begin{array}{l}\text { Better effect of } \\
\text { ABO-BoNT/A at 1:3 } \\
\text { and 1:4 ratios } \\
\text { AEs: higher with both } \\
\text { ABO-BoNT/A treatments } \\
\text { Dysphagia: } \\
\text { ONA-BoNT/A 3\%, ABO- } \\
\text {-BoNT/A 15.6\%, and 17.3\% } \\
\text { for conversion ratios 1:3 } \\
\text { and 1:4, respectively }\end{array}$ \\
\hline $\begin{array}{l}\text { Marchetti } \\
\text { et al. } 2005 \\
{[11]}\end{array}$ & $\begin{array}{l}\text { Multicentre evaluation } \\
\text { real-world dose utilisa- } \\
\text { tion of } A B O-B o N T / A \text { and } \\
\text { ONA-BoNT/A for CD } \\
\text { and BS }\end{array}$ & $\begin{array}{l}\mathrm{n}=114 \text { (both for BS } \\
\text { and CD) } \\
\text { Patients received ABO- } \\
\text {-BoNT/A or ONA-BoNT/A } \\
\text { for at least one year } \\
\text { before and after drug } \\
\text { crossover }\end{array}$ & $\begin{array}{l}\text { Ratios of mean dose } \\
\text { for } A B O-\text { and ONA- } \\
\text {-BoNT/A ranged } \\
\text { from } 2: 1 \text { to } 11: 1\end{array}$ & $\begin{array}{l}\text { Anatomical landmarks, doses } \\
\text { and muscles injected were } \\
\text { determined by physician } \\
\text { based on individual clinical } \\
\text { presentation and outcome }\end{array}$ & $\begin{array}{l}\text { ABO- vs. ONA-BoNT/A } \\
5: 1 \text { to less than } 6: 1,(31 \%) \\
4: 1 \text { to less than } 5: 1,(30 \%) \\
3: 1 \text { to less than } 4: 1,(21 \%)\end{array}$ \\
\hline $\begin{array}{l}\text { Benecke } \\
\text { et al. } 2005 \\
{[30]}\end{array}$ & $\begin{array}{l}\text { DB non-inferiority study } \\
\text { comparing INCO-and } \\
\text { ONA-BoNT/A }\end{array}$ & $\begin{array}{l}\mathrm{n}=463 \\
\text { TWSTRS, pain scores, } \\
\text { duration, adverse events }\end{array}$ & $\begin{array}{l}\text { Fixed dose conver- } \\
\text { sion ratio 1:1 }\end{array}$ & $\begin{array}{l}\text { Anatomical landmarks; doses } \\
\text { and muscles injected were } \\
\text { determined by physician } \\
\text { based on individual clinical } \\
\text { presentation }\end{array}$ & $\begin{array}{l}\text { Effect, duration and AEs } \\
\text { similar for both }\end{array}$ \\
\hline $\begin{array}{l}\text { Rystedt } \\
\text { et al. } 2015 \\
{[28]}\end{array}$ & $\begin{array}{l}\text { DB, randomised cross- } \\
\text { over, ONA- BoNT/A and } \\
\text { ABO-BoNT/A in two } \\
\text { different dose conversion } \\
\text { ratios ( } 1: 3 \text { and } 1: 1.7)\end{array}$ & $\begin{array}{l}\mathrm{n}=46 \mathrm{pts} \\
\text { TWSTRS }\end{array}$ & $\begin{array}{l}\text { Two different } \\
\text { dose conversion } \\
\text { ratios (1:3 and 1:1.7), } \\
\text { diluted to same } \\
\text { concentration (100 } \\
\mathrm{U} / \mathrm{mL} \text { ) }\end{array}$ & $\begin{array}{l}\text { Anatomical landmarks; doses } \\
\text { and muscles injected were } \\
\text { determined by physician } \\
\text { based on individual clinical } \\
\text { presentation }\end{array}$ & $\begin{array}{l}\text { Similar effect at week } 4 \\
\text { (TWSTRS) } \\
\text { Shorter duration of effect } \\
\text { for ONA- BoNT/A } \\
\text { AEs: similar }\end{array}$ \\
\hline $\begin{array}{l}\text { Yun et al. } \\
2015 \text { [29] }\end{array}$ & $\begin{array}{l}\text { DB, randomised,multi- } \\
\text { centre, non-inferiority, } \\
\text { two-period crossover } \\
\text { study }\end{array}$ & $\begin{array}{l}\mathrm{n}=103 \\
\text { Tsui scores, TWSTRS pain } \\
\text { scores, adverse events }\end{array}$ & $\begin{array}{l}\text { Fixed dose conver- } \\
\text { sion ratio } 1: 2.5 \text { be- } \\
\text { tween ONA-BoNT/A } \\
\text { and ABO-BoNT/A, } \\
\text { concentration ( } 100 \\
\mathrm{U} / \mathrm{mL} \text { ) }\end{array}$ & $\begin{array}{l}\text { Anatomical landmarks; doses } \\
\text { and muscles injected were } \\
\text { determined by physician } \\
\text { based on individual clinical } \\
\text { presentation }\end{array}$ & Similar effects and AEs \\
\hline
\end{tabular}

RCT — Randomised Controlled Trial; DB — double-blind; TWSTRS — Toronto Western Spasmodic Torticollis Rating Scale

proportion of improvement in clinical global impression and patient global impression, and the incidences of adverse events, were not significantly different between the two treatments. In conclusion, the study showed no differences between the $\mathrm{ABO}$ - and ONA-BoNT/A at a conversion rate of 2.5:1 [29].

\section{ONA-BoNT/A vs. INCO-BoNT/A}

In a study comparing the effectiveness of treatment with ONA- vs. INCO- BoNT/A, Benecke et al. included a large group of 463 patients [23]. The efficacy and safety of both preparations were compared in a 1:1 dose ratio (209 patients treated with INCO- and 205 with ONA-BoNT/A) and observed for 16 weeks. Groups did not differ significantly regarding TWSTRS scores, pain intensity, duration of improvement, or side effects [30].

\section{Single medication studies}

We identified 11 randomised, double-blind studies on the treatment of $\mathrm{CD}$ with the use of various BoNT/A 
Table 4. Selected studies on BoNT/A in treatment of cervical dystonia (single toxin with indirect comparisons only possible)

\begin{tabular}{|c|c|c|c|c|c|}
\hline References & Study design & $\begin{array}{l}\text { Patients characte- } \\
\text { ristics and outco- } \\
\text { me measure }\end{array}$ & $\begin{array}{l}\text { BoNT/A and } \\
\text { dose (U) }\end{array}$ & $\begin{array}{l}\text { Muscles injected/ injection } \\
\text { guide }\end{array}$ & $\begin{array}{l}\text { Efficacy outcome/ adverse } \\
\text { events }\end{array}$ \\
\hline $\begin{array}{l}\text { Poewe et al. } \\
1998 \text { [34] }\end{array}$ & $\begin{array}{l}\mathrm{RCT} \text {, double-blind, } \\
\text { dose-ranging, } \\
\text { placebo-con- } \\
\text { trolled }\end{array}$ & $\begin{array}{l}\mathrm{n}=75 \\
\text { Tsui scale, pain scale } \\
\text { and global assess- } \\
\text { ment at weeks } 2,4 \\
\text { and } 8, \text { AEs }\end{array}$ & $\begin{array}{l}\text { ABO- BoNT/A, } \\
250,500 \\
1,000 \mathrm{U}, \\
\text { placebo }\end{array}$ & $\begin{array}{l}\text { Anatomical landmarks, fixed } \\
\text { muscles: splenius capitis and } \\
\text { contralateral sternocleidomas- } \\
\text { toid }\end{array}$ & $\begin{array}{l}\text { Significant improvement at week } 4 \\
\text { for both doses }\end{array}$ \\
\hline $\begin{array}{l}\text { Truong et al. } \\
2005[35]\end{array}$ & $\begin{array}{l}\text { RCT, double-blind, } \\
\text { multicentre, pla- } \\
\text { cebo-controlled }\end{array}$ & $\begin{array}{l}\mathrm{n}=80 \\
\text { TWSTRS, pain scale } \\
\text { and self-report visual } \\
\text { analogue scale (VAS) }\end{array}$ & $\begin{array}{l}\text { ABO- BoNT/A } \\
500 \text { U, placebo }\end{array}$ & $\begin{array}{l}\text { Study medication administered } \\
\text { by intramuscular injection into } \\
\text { two, three, or four clinically in- } \\
\text { dicated neck muscles in a single } \\
\text { dosing session, with or without } \\
\text { EMG guidance. Investigator } \\
\text { determined number of injection } \\
\text { sites per muscle and dose at } \\
\text { each site }\end{array}$ & $\begin{array}{l}\text { Significant improvement at weeks } \\
4,8 \text {, and } 12 \\
\text { Median duration: } 18.5 \text { weeks } \\
\text { AEs: similar, except blurred vision } \\
\text { ( } 14 \text { vs. } 0 \% \text { ) and muscle weakness } \\
\text { (11 vs } 0 \% \text { ) in ABO-BoNT/A vs. place- } \\
\text { bo group, Dysphagia ( } 16 \text { vs. } 9 \%) \text {, but } \\
\text { not significant }\end{array}$ \\
\hline $\begin{array}{l}\text { Comella et al. } \\
2011[36]\end{array}$ & $\begin{array}{l}\text { RCT, double-blind, } \\
\text { multicentre } \\
\text { dose-ranging, } \\
\text { placebo con- } \\
\text { trolled }\end{array}$ & $\begin{array}{l}n=223 \\
\text { TWSTRS total score } \\
\text { (baseline vs. week } 4 \\
\text { AEs }\end{array}$ & $\begin{array}{l}\text { INCO- BoNT/A } \\
120 U, 240 \text { U, or } \\
\text { placebo }\end{array}$ & $\begin{array}{l}\text { Anatomical landmarks, number } \\
\text { of injection sites per muscle, } \\
\text { volume injected into each mus- } \\
\text { cle, and use of EMG guidance } \\
\text { were determined at discretion of } \\
\text { investigator }\end{array}$ & $\begin{array}{l}\text { Improvement at week } 4 \\
\text { AEs: dysphagia ( } 2.7 \% \text { vs. } 11.5 \% \\
\text { vs. } 24 \% \text { in placebo, } 120 \text { and } 240 \mathrm{U} \\
\text { respectively) }\end{array}$ \\
\hline $\begin{array}{l}\text { Charles et al. } \\
2012 \text { [37] }\end{array}$ & $\begin{array}{l}\text { RCT, double-blind, } \\
\text { multicentre, pla- } \\
\text { cebo-controlled }\end{array}$ & $\begin{array}{l}\mathrm{n}=170 \\
\text { CDSS and physician } \\
\text { GAS at week } 6\end{array}$ & $\begin{array}{l}\text { ONA-BoNT/A } \\
95-360 \mathrm{U} \\
\text { (mean } 236 \mathrm{U}) \text {, } \\
\text { or placebo }\end{array}$ & $\begin{array}{l}\text { Anatomical landmarks, doses } \\
\text { and muscles injected were de- } \\
\text { termined by physician based on } \\
\text { individual clinical presentation } \\
\text { and previously established } \\
\text { treatment regimen }\end{array}$ & $\begin{array}{l}\text { Improvement at week } 6 \\
\text { AEs: rhinitis ( } 6.8 \% \text { and } 3.7 \% \text { in } \\
\text { double -blind and open period vs. } \\
0 \% \text { placebo. Statistically significant } \\
\text { dysphagia ( } 6.8 \% \text { vs. } 8.4 \% \text { vs. } 3.7 \% \\
\text { placebo in double-blind open peri- } \\
\text { od, not statistically significant) }\end{array}$ \\
\hline
\end{tabular}

RCT — Randomised Controlled Trial; TWSTRS — Toronto Western Spasmodic Torticollis Rating Scale; VAS — Visual Analogue Scale; GAS — Global Assessment Scale; CDSS — Cervical Dystonia Severity Scale; EMG - electromyography

preparations. All these studies showed that BoNT/A is effective in $\mathrm{CD}$ therapy over a placebo. However, the used doses to achieve the effect of improvement were 500-1,000 $\mathrm{U}$ of ABO-BoNT/A, 95-360 U of ONA-BoNT/A, and 120-240 U of INCO-BoNT/A [31-38].

The use of EMG or US guidance $v s$. no guidance may have influenced the amount of BoNT/A needed, but it was not controlled for in any of these studies.

\section{Conclusions}

- The treatment of CD is very challenging. Many factors can influence outcomes, such as: a proper pattern of CD recognition, utilising different approaches in terms of muscle selection (e.g. adopting Col-Cap concept), and injection guidance with EMG or ultrasound [39-42]

- Reviewing all cited studies, we note various approaches from real life practice up to pre-fixed ratios, different solutions, various scales used, and timelines

- The range of conversion ratios between all three products extracted from all studies is wide (ONA- vs. INCO-BoNT/A 1:1, and between ONA- and ABO-BoNT/A from $1: 1.7$ to $1: 5)$
- Regarding the studies performed, in comparing different BoNT/A preparations it is impossible to establish a fixed ratio between doses. When switching patients from one to another, one must respect the SPC specific recommendations.

\section{Upper limb spasticity}

Botulinum neurotoxin-A is widely used in clinical practice for the treatment of this major complication following a stroke, affecting $30-40 \%$ of patients $[43,44]$. Nevertheless, to date there have been no guidelines offering a unified dosage standard for consecutive muscles and different BoNT/A formulations. All three major formulations recommend different muscles and doses in their SPCs. The total dose per treatment session varies from $400 \mathrm{U}$ for ONA-, $500 \mathrm{U}$ for INCO-, and 1,500 U for ABO-BoNT/A [4-6]. Table 5 sets out the muscle patterns and doses extracted from SPCs of three products. With the aim of finding the possible conversion ratio between different BoNT/A products, we analysed the most important studies on the treatment of ULS with all three preparations. Adhering to the methodology that we have adopted for this 
Table 5. Product registration recommendations in upper limb spasticity treatment for three major BoNT/A preparations

\begin{tabular}{|c|c|c|c|}
\hline Recommended muscle & $\begin{array}{c}\text { ONA-BoNT/A (Botox) } \\
\text { (recommended dose range) }\end{array}$ & $\begin{array}{c}\text { ABO-BoNT/A (Dysport) } \\
\text { (recommended dose range) }\end{array}$ & $\begin{array}{l}\text { INCO-BoNT/A (Xeomin) } \\
\text { (recommended dose range) }\end{array}$ \\
\hline Flexor carpi radialis & $15-50 \mathrm{U}$ & $100-200 \mathrm{U}$ & $25-100 \mathrm{U}$ \\
\hline Flexor carpi ulnaris & $10-50 \mathrm{U}$ & $100-200 \mathrm{U}$ & $20-100 \mathrm{U}$ \\
\hline Flexor digitorum profundus & $15-50 \mathrm{U}$ & $100-200 \mathrm{U}$ & $25-100 \mathrm{U}$ \\
\hline Flexor digitorum superficialis & $15-50 \mathrm{U}$ & $100-200 \mathrm{U}$ & $25-100 \mathrm{U}$ \\
\hline Adductor pollicis & $20 \mathrm{U}$ & $25-50 \mathrm{U}$ & $5-30 \mathrm{U}$ \\
\hline Flexor pollicis longus & $20 \mathrm{U}$ & $100-200 \mathrm{U}$ & $10-50 \mathrm{U}$ \\
\hline $\begin{array}{l}\text { Flexor pollicis brevis / opponens } \\
\text { pollicis }\end{array}$ & - & - & $5-30 U$ \\
\hline Brachialis & - & $200-400 \mathrm{U}$ & $25-100 \mathrm{U}$ \\
\hline Biceps brachii & - & $200-400 \mathrm{U}$ & $50-200 \mathrm{U}$ \\
\hline Brachio-radialis & - & $100-200 \mathrm{U}$ & $25-100 \mathrm{U}$ \\
\hline Pronator teres & - & $100-200 \mathrm{U}$ & $25-75 \mathrm{U}$ \\
\hline Pronator quadratus & - & - & $10-50 \mathrm{U}$ \\
\hline Triceps brachii (long head) & - & $150-300 \mathrm{U}$ & - \\
\hline Pectoralis major & - & $150-300 \mathrm{U}$ & $20-200 \mathrm{U}$ \\
\hline Subscapularis & - & $150-300 \mathrm{U}$ & $15-100 \mathrm{U}$ \\
\hline Latissimus dorsi & - & $150-300 \mathrm{U}$ & $25-150 \mathrm{U}$ \\
\hline Deltoideus & - & - & $20-150 \mathrm{U}$ \\
\hline Teres major & - & - & $20-100 \mathrm{U}$ \\
\hline $\begin{array}{l}\text { Maximal recommended dose per } \\
\text { treatment session (according to SPCs) }\end{array}$ & $400 \mathrm{U}$ & $1,500 \mathrm{U}$ & $500 \mathrm{U}$ \\
\hline
\end{tabular}

paper, we included in our analysis double-blind, randomised, placebo-controlled trials evaluating the efficacy and safety of various preparations of BoNT/A in the treatment of upper limb spasticity (Tab. 6) [45-58]. Almost all studies evaluated BoNT/A effectiveness in post-stroke (PS) spasticity, except for Gracies et al. [54] which included post-stroke patients as well as subjects with post-traumatic brain injury.

We did not identify studies directly comparing the clinical efficacy and safety of all three BoNT/A products. All of them compared the BoNT/A preparations versus a placebo. Based on studies included in our analysis, direct comparisons of the efficacy and tolerability of these three products are impossible. Indirect comparisons of the results are also limited and inconclusive due to different patient characteristics and various treatment and evaluation methods, e.g. injected muscle groups, guidance, used scales, or follow-up duration. These different approaches can be seen in Table 6 where we set out major data from trials.

\section{Conclusions}

- All studies confirm the effectiveness (in terms of reduction of muscle tone and in some also in simple functions) and safety of the used doses of BoNT/A market products in the treatment of ULS for a wide range of maximal doses: ONA-BoNT/A: 120-400 U; ABO-BoNT/A: 100-1,000 U; and INCO-BoNT/A: 150-400 U
- The choice of medical preparation and dose of BoNT/A should be adapted to individual patient need, but it is recommended not to exceed the maximum doses per treatment session according to the SPC

- However, in a few studies higher doses were used safely: $1,500 \mathrm{U}$ of ABO-, $600 \mathrm{U}$ of ONA- and $800 \mathrm{U}$ of INCO-BoNT/A $[59,60]$. Looking at these dosages, it is impossible to translate one result into another using a simple conversion ratio. We cannot present the recommended conversion ratio. Switching patients from one preparation to another should therefore respect the product characteristics recommendations.

\section{Lower limb spasticity}

Product characteristics of ONA-BoNT/A recommend the administration of 300-400 $\mathrm{U}$ in a single treatment session of focal lower limb spasticity (LLS). The total injected dose of BoNT/A should be divided among up to six muscles ( $m$. gastrocnemius, $m$. soleus, $m$. tibialis posterior, $m$. flexor hallucis longus, $m$. flexor digitorum longus, and $m$. flexor digitorum brevis), whereas $\mathrm{SPC}$ of $\mathrm{ABO}-\mathrm{BoNT} / \mathrm{A}$ recommend doses of up to $1,500 \mathrm{U}$ with a spread in the distal muscles ( $m$. soleus, $m$. gastrocnemius, $m$. tibialis posterior, $m$. flexor digitorum longus, $m$. flexor digitorum brevis, $m$. flexor hallucis longus, $m$. flexor hallucis brevis) as well as in the proximal muscles of the lower limb 
Table 6. Selected studies on BoNT/A in treatment of upper limb spasticity

\begin{tabular}{|c|c|c|c|c|c|}
\hline References & Study design & $\begin{array}{l}\text { Patient characteristics } \\
\text { and outcome measures }\end{array}$ & $\begin{array}{l}\text { BoNT-A } \\
\text { and dose (U) }\end{array}$ & $\begin{array}{l}\text { Muscles injected/ } \\
\text { /njection guide }\end{array}$ & $\begin{array}{l}\text { Efficacy outcome/ } \\
\text { /adverse events }\end{array}$ \\
\hline $\begin{array}{l}\text { Bakheit et al. } \\
2001[45]\end{array}$ & $\begin{array}{l}\text { RCT, mul- } \\
\text { ti-centre, } \\
\text { double-blind, } \\
\text { placebo-con- } \\
\text { trolled }\end{array}$ & $\begin{array}{l}\mathrm{n}=59 \\
\text { PS - over } 3 \text { months } \\
\text { MAS, PROM, BI, pain sore, } \\
\text { GAS, physician and patient } \\
\text { global assessment of benefit }\end{array}$ & $\begin{array}{l}1,000 \mathrm{U} \\
\mathrm{ABO}-\mathrm{BoNT} / \mathrm{A} \\
\text { and } \\
\text { placebo }\end{array}$ & $\begin{array}{l}\text { BB, FCR, FCU, FDS, } \\
\text { FDP / } \\
\text { according to anatom- } \\
\text { ical landmarks }\end{array}$ & $\begin{array}{l}\text { Improvement at week } 16 \\
\text { AEs: in } 16 \text { in ABO-BoNT/A group } \\
\text { and in } 20 \text { in placebo group (mainly } \\
\text { accidental injury, respiratory and } \\
\text { urinary tract infections) }\end{array}$ \\
\hline $\begin{array}{l}\text { Brashear } \\
\text { et al. } \\
2002[46]\end{array}$ & $\begin{array}{l}\text { RCT, mul- } \\
\text { ti-centre, } \\
\text { double-blind, } \\
\text { placebo-con- } \\
\text { trolled }\end{array}$ & $\begin{array}{l}n=126 \\
\text { PS - over } 6 \text { months with AS } \\
\text { scores of at least } 3 \text { in the wrist } \\
\text { and at least } 2 \text { in the fingers; } \\
\text { AS for wrist, fingers, thumb; } \\
\text { DAS in principal target } \\
\text { domain (limb position, dress- } \\
\text { ing, hygiene, pain), GAS, } \\
\text { measurement of neutralising } \\
\text { antibodies, AEs }\end{array}$ & $\begin{array}{l}200-240 \mathrm{U} \\
\text { ONA-BoNT/A } \\
\text { or } \\
\text { placebo }\end{array}$ & $\begin{array}{l}\text { FCR, FCU, FDS, FDP, } \\
\text { FPL, ADDP / NA }\end{array}$ & $\begin{array}{l}\text { Improvement up to } 12 \text { weeks; } \\
\text { No major AEs }\end{array}$ \\
\hline $\begin{array}{l}\text { Childers et al. } \\
2004 \text { [47] }\end{array}$ & $\begin{array}{l}\text { RCT, mul- } \\
\text { ti-centre, dou- } \\
\text { ble-blind, place- } \\
\text { bo-controlled, } \\
\text { dose-ranging }\end{array}$ & $\begin{array}{l}n=90 \\
\text { PS - mean } 25.8 \text { months } \\
\text { from stroke onset (0.9-226.9 } \\
\text { months) } \\
\text { with wrist, elbow, and finger } \\
\text { flexor spasticity } \\
\text { MAS, physician and patient } \\
\text { global assessments, pain, FIM } \\
\text { and SF-36, AEs }\end{array}$ & $\begin{array}{l}\text { E1: } 90 \mathrm{U} \\
\text { ONA-BoNT/A } \\
\text { E2: } 180 \mathrm{U} \\
\text { ONA-BoNT/A } \\
\text { E3: } 360 \mathrm{U} \\
\text { ONA-BoNT/A } \\
\text { or } \\
\text { placebo }\end{array}$ & $\begin{array}{l}\text { BB, FCR, FCU, FDS, } \\
\text { FDP / } \\
\text { EMG guidance }\end{array}$ & $\begin{array}{l}\text { Dose dependent MAS reduction } \\
\text { in: wrist and elbow flexors up to } 9 \\
\text { weeks, and in finger flexors up to } \\
3 \text { weeks. } \\
\text { No significant changes in pain, FIM } \\
\text { or SF-36 } \\
\text { AEs in } 83.1 \%(54 / 65) \text { of ONA- } \\
\text {-BoNT/A group and } 65.4 \%(17 / 26) \text { of } \\
\text { placebo group }\end{array}$ \\
\hline $\begin{array}{l}\text { McCorry et } \\
\text { al. } 2009 \\
{[48]}\end{array}$ & $\begin{array}{l}\text { RTC, mul- } \\
\text { ti-centre, } \\
\text { double-blind, } \\
\text { placebo-con- } \\
\text { trolled }\end{array}$ & $\begin{array}{l}n=96 \\
\text { PS - over } 6 \text { months with } \\
\geq 2 \text { on MAS for at least two } \\
\text { of elbow, wrist and finger } \\
\text { flexors; } \\
\text { AQoL, GAS, VAS for pain } \\
\text { evaluation, HADs, MAS, } \\
\text { MMAS, Carer Burden Scale, } \\
\text { Patient Disability Scale, Global } \\
\text { Assessment of Benefit by } \\
\text { investigator and patient, AEs }\end{array}$ & $\begin{array}{l}750-1,000 \mathrm{U} \\
\mathrm{ABO}-\mathrm{B} 0 \mathrm{NT} / \mathrm{A} \text { in first } \\
\text { cycle, } 500-1,000 \mathrm{U} \\
\text { in second cycle } \\
\text { or } \\
\text { placebo }\end{array}$ & $\begin{array}{l}\text { BB, BR, B-R, TRIC, FCR, } \\
\text { FCU, FDS, FDP, FPL/ } \\
\text { ADDP/FPB / } \\
\text { EMG and/or ES guid- } \\
\text { ance }\end{array}$ & $\begin{array}{l}\text { Significant reduction in spasticity } \\
\text { (MAS), higher GAS scores and great- } \\
\text { er global benefit up to } 20 \text { weeks in } \\
\text { ONA-BoNT/A vs. placebo } \\
\text { No changes in AQoL; } \\
\text { AEs: treatment-related in } 5.5 \% \text { of } \\
\text { ONA-BoNT-A and } 9.5 \% \text { placebo }\end{array}$ \\
\hline $\begin{array}{l}\text { Kanovsky et } \\
\text { al. } 2009 \\
\text { [49] }\end{array}$ & $\begin{array}{l}\text { RTC, mul- } \\
\text { ti-centre, } \\
\text { double-blind, } \\
\text { placebo-con- } \\
\text { trolled }\end{array}$ & $\begin{array}{l}n=148 \\
\text { PS - over } 6 \text { months with } \geq 2 \\
\text { AS for wrist and finger flexors; } \\
\text { AS, DAS, Carer Burden } \\
\text { Scale, Global Assessment of } \\
\text { Treatment Benefit by investi- } \\
\text { gator, patient and caregiver, } \\
\text { development of neutralising } \\
\text { antibodies, AEs }\end{array}$ & $\begin{array}{l}\text { Up to } 400 \mathrm{U} \\
\text { (mean } 320 \mathrm{U} \text { ) } \\
\text { INCO-BoNT/A } \\
\text { or } \\
\text { placebo }\end{array}$ & $\begin{array}{l}\text { Principal therapeutic } \\
\text { target was flexed } \\
\text { wrist and clenched } \\
\text { fist (FCR, FCU, FDS, } \\
\text { FDP), and additional- } \\
\text { ly as needed: BB, BR, } \\
\text { B-R, ADDP, OPPP, FPL, } \\
\text { FPB, PT, PQ / } \\
\text { EMG and/or ES } \\
\text { guidance }\end{array}$ & $\begin{array}{l}\text { Improvement of } \geq 1 \text { point in AS } \\
\text { score at } 4 \text { weeks, improvement until } \\
\text { week } 12 \text { in principal therapeutic } \\
\text { target, and in some tasks of Carer } \\
\text { Burden Scale } \\
\text { AE in } 21 \text { pts }(28.8 \%) \text { in INCO-BoNT/A } \\
\text { and } 20(26.7 \%) \text { in placebo group; } \\
\text { incidence of AEs were similar }\end{array}$ \\
\hline $\begin{array}{l}\text { Kaji et al. } \\
2010[50]\end{array}$ & $\begin{array}{l}\text { RTC, mul- } \\
\text { ti-centre, dou- } \\
\text { ble-blind, place- } \\
\text { bo-controlled, } \\
\text { dose-ranging }\end{array}$ & $\begin{array}{l}n=109 \\
\text { PS over } 6 \text { months with focal } \\
\text { pattern of both wrist and } \\
\text { fingers, } 3 \text { or } 4 \text { MAS for wrist } \\
\text { flexors, and } 2+\text { for finger } \\
\text { flexors on } \\
\text { MAS for wrist, finger flexors } \\
\text { and thumb, DAS, CGI, ADL, } \\
\text { AEs }\end{array}$ & $\begin{array}{l}\text { E1: } 120-150 \mathrm{U} \\
\text { ONA-BoNT/A } \\
\text { E2: } 200-240 \mathrm{U} \\
\text { ONA-BoNT/A } \\
\text { or } \\
\text { placebo }\end{array}$ & $\begin{array}{l}\text { FCR, FCU, FDP, FDS, } \\
\text { FPL, ADDP / EMG or } \\
\text { ES guidance }\end{array}$ & $\begin{array}{l}\text { Reduction of spasticity and im- } \\
\text { provement in ADL in limb position } \\
\text { and dressing in E2; E2 more effec- } \\
\text { tive than E1 in reduction of wrist } \\
\text { spasticity; } \\
\text { investigator's and patient's CGI } \\
\text { significantly higher in E2 compared } \\
\text { to placebo group; } \\
\text { patient's CGI significantly higher at } \\
\text { weeks } 1 \text { and } 4 \text { in E1 compared to } \\
\text { placebo group; } \\
\text { AEs: } 47 \% \text { in E2, 38\% in E1 and } 57 \% \\
\text { in placebo group }\end{array}$ \\
\hline
\end{tabular}


Table 6 cont. Selected studies on BoNT/A in treatment of upper limb spasticity

\begin{tabular}{|c|c|c|c|c|c|}
\hline References & Study design & $\begin{array}{l}\text { Patient characteristics } \\
\text { and outcome measures }\end{array}$ & $\begin{array}{l}\text { BoNT-A } \\
\text { and dose (U) }\end{array}$ & $\begin{array}{l}\text { Muscles injected/ } \\
\text { /njection guide }\end{array}$ & $\begin{array}{l}\text { Efficacy outcome/ } \\
\text { /adverse events }\end{array}$ \\
\hline $\begin{array}{l}\text { Wolf et al. } \\
2012 \text { [51] }\end{array}$ & $\begin{array}{l}\text { RCT, prospective, } \\
\text { single-centre, } \\
\text { double-blind, } \\
\text { placebo-con- } \\
\text { trolled }\end{array}$ & $\begin{array}{l}n=25 \\
\text { PS after 3-24 months with } \\
\text { unilateral ULS } \\
\text { focal spasticity in wrist or } \\
\text { fingers, ability to initiate wrist } \\
\text { extension of at least } 10^{\circ} \text { from } \\
\text { a fully flexed position; } \\
\text { WMFT, MAS, AROM, SIS (qual- } \\
\text { ity of life), AEs }\end{array}$ & $\begin{array}{l}\text { ONA-BoNT/A } 300 \mathrm{U} \\
\text { or } \\
\text { placebo }\end{array}$ & $\begin{array}{l}\text { Wrist and fingers } \\
\text { flexors / according } \\
\text { to anatomical land- } \\
\text { marks }\end{array}$ & $\begin{array}{l}\text { Improvement in MAS } \\
\text { No significant changes in WMFT, } \\
\text { AROM, SIS; } \\
\text { AEs: one related to study (swelling } \\
\text { and localised haematoma after } \\
\text { injections) }\end{array}$ \\
\hline $\begin{array}{l}\text { Marciniak } \\
\text { et al. } 2012 \\
{[52]}\end{array}$ & $\begin{array}{l}\text { RCT, prospective, } \\
\text { two-centre, } \\
\text { double-blind, } \\
\text { placebo-con- } \\
\text { trolled }\end{array}$ & $\begin{array}{l}n=21 \\
\text { PS - over } 6 \text { months with } 3 \text { or } 4 \\
\text { MAS for shoulder adductors/ } \\
\text { internal rotator and shoulder } \\
\text { pain; } \\
\text { MAS, PROM, daily pain } \\
\text { ratings using VAS, DAS for } \\
\text { dressing, hygiene, pain and } \\
\text { cosmesis, FIM - upper body } \\
\text { dressing, hygiene, McGill Pain } \\
\text { Questionnaire Short Form; } \\
\text { Fugl-Meyer Scale, AEs }\end{array}$ & $\begin{array}{l}\text { ONA-BoNT/A } \\
140-200 \mathrm{U} \\
\text { or } \\
\text { placebo }\end{array}$ & $\begin{array}{l}\text { PECM (100-150 U), } \\
\text { TM ( } 40-60 \mathrm{U}) / \text { ac- } \\
\text { cording to anatomi- } \\
\text { cal landmarks }\end{array}$ & $\begin{array}{l}\text { Improvement in MAS, PROM, DAS } \\
\text { for hygiene and Fugl-Meyer Scale } \\
\text { No significant changes in FIM; } \\
\text { AEs: none treatment-related }\end{array}$ \\
\hline $\begin{array}{l}\text { Rosales et al. } \\
2012 \text { [53] }\end{array}$ & $\begin{array}{l}\text { RCT, prospective, } \\
\text { multi-centre, } \\
\text { double-blind, } \\
\text { placebo-con- } \\
\text { trolled }\end{array}$ & $\begin{array}{l}n=163 \\
\text { PS after 2-12 weeks with MAS } \\
\geq 1+\text { in elbow or wrist joint, } \\
\text { Asian ethnicity; } \\
\text { MAS, BI, mRS, Functional } \\
\text { Motor Assessment } \\
\text { Scale scores, PROM, AROM }\end{array}$ & $\begin{array}{l}\text { ABO-BoNT/A } 500 \mathrm{U} \\
\text { and unstructured } \\
\text { rehabilitation } \\
\text { programme } \\
\text { or } \\
\text { placebo and un- } \\
\text { structured rehabili- } \\
\text { tation programme }\end{array}$ & $\begin{array}{l}\text { BB, BR, FCR, FCU, FDP, } \\
\text { FDS, FPL / NA }\end{array}$ & $\begin{array}{l}\text { Significant improvement in MAS at } \\
\text { all time points ( } 24 \text { weeks), improve- } \\
\text { ment in PROM and active finger } \\
\text { movements (hand closed) } \\
\text { at weeks 4, 8, and 12; no significant } \\
\text { changes in BI, mRS, Functional } \\
\text { Motor Assessment scores; } \\
\text { AEs: } 48 \text { (57\%) in ABO-BoNT/A and } \\
36(43 \%) \text { in placebo group }\end{array}$ \\
\hline $\begin{array}{l}\text { Gracies et al. } \\
2015[54]\end{array}$ & $\begin{array}{l}\text { RCT, prospective, } \\
\text { multi-centre, } \\
\text { double-blind, } \\
\text { placebo-con- } \\
\text { trolled }\end{array}$ & $\begin{array}{l}n=243 \\
\text { PS or PTBI - over } 6 \text { months, } \\
\text { MAS in the PTMG } \geq 2 \\
\text { PGA of treatment response } \\
\text { using a 9-point scale, DAS in } \\
\text { principal target domain (hy- } \\
\text { giene, dressing, limb position, } \\
\text { pain) }\end{array}$ & $\begin{array}{l}\text { E1: ABO-BoNT/A } \\
500 \mathrm{U} \\
\text { E2: ABO-BoNT/A } \\
1,000 \mathrm{U} \\
\text { or } \\
\text { placebo }\end{array}$ & $\begin{array}{l}\text { PTMG among elbow, } \\
\text { wrist, or finger } \\
\text { flexors, and into at } \\
\text { least two additional } \\
\text { muscle groups from } \\
\text { elbow, wrist, or finger } \\
\text { flexors or shoulder } \\
\text { extensors } \\
\text { ES guidance }\end{array}$ & $\begin{array}{l}\text { MAS score reduction in PTMG in E1 } \\
\text { and E2 groups; superiority in PGA; } \\
\text { no significant improvements in DAS; } \\
\text { AEs: treatment related in } 2 \text { ( } 2 \%), 6 \\
\text { (7\%), and } 7 \text { ( } 9 \% \text { ) pts in placebo, E1 } \\
\text { and E2 groups, respectively (most } \\
\text { commonly mild muscle weakness). } \\
\text { All AEs - mild or moderate }\end{array}$ \\
\hline $\begin{array}{l}\text { Elovic et al. } \\
2016 \text { [55] }\end{array}$ & $\begin{array}{l}\text { RCT, prospective, } \\
\text { multi-centre, } \\
\text { double-blind, } \\
\text { placebo-con- } \\
\text { trolled }\end{array}$ & $\begin{array}{l}n=317 \\
\text { PS - over } 3 \text { months with } \\
\text { flexed elbow, flexed wrist, and } \\
\text { clenched fist with } \\
\text { AS } \geq 2 \text { on at each site and } \\
\text { a clinical need for a total dose } \\
\text { of } 400 \text { U of INCO-BoNT/A; } \\
\text { AS of PTMG, Investigator's } \\
\text { Global Impression of Change } \\
\text { using a 7-point balanced } \\
\text { Likert scale; DAS in principal } \\
\text { target domain (hygiene, } \\
\text { dressing, limb position, pain) }\end{array}$ & $\begin{array}{l}\text { INCO-BoNT/A } 400 \mathrm{U} \\
\text { or } \\
\text { placebo }\end{array}$ & $\begin{array}{l}1 \text { PTMG: flexed elbow } \\
-200 \mathrm{U} \text { or flexed } \\
\text { wrist - } 150 \mathrm{U} \\
\text { or clenched fist } \\
\text { - } 100 \mathrm{U} \text { and other } \\
\text { muscle groups - in- } \\
\text { vestigators decided } \\
\text { dose and number } \\
\text { of injection sites per } \\
\text { muscle within prede- } \\
\text { fined ranges } \\
\text { EMG and/or ES } \\
\text { guidance }\end{array}$ & $\begin{array}{l}\text { Improvements in PTMG in AS, } \\
\text { superiority in Investigator's Global } \\
\text { Impression of Change, functional } \\
\text { improvements in DAS; } \\
\text { AEs: } 47 \text { of } 210 \text { subjects. AE of special } \\
\text { interest in } 7 \text { subjects ( } 3.3 \% \text { ), most } \\
\text { commonly dry mouth ( } 4 \text { subjects) }\end{array}$ \\
\hline $\begin{array}{l}\text { Rosales et al. } \\
2018[56]\end{array}$ & $\begin{array}{l}\text { RCT, prospective } \\
\text { multi-centre, } \\
\text { double-blind, } \\
\text { placebo-con- } \\
\text { trolled }\end{array}$ & $\begin{array}{l}n=42 \\
P S-2-12 \text { weeks with MAS } \\
\geq 2 ; \\
\text { time between UL injection, } \\
\text { MAS, UL active motor func- } \\
\text { tion, time to reach re-injection } \\
\text { criteria, global assessment of } \\
\text { change }\end{array}$ & $\begin{array}{l}\text { ABO-BoNT/A } 500 \mathrm{U} \\
\text { or } \\
\text { placebo }\end{array}$ & $\begin{array}{l}\text { PTMG (most } \\
\text { commonly - elbow } \\
\text { flexors) / NA }\end{array}$ & $\begin{array}{l}\text { Increased time to re-injection, pro- } \\
\text { longed MAS improvements } \\
\text { AEs: } 23 \text { adverse events in } 12 \\
\text { patients; mostly mild-to-moderate } \\
\text { intensity }\end{array}$ \\
\hline
\end{tabular}


Table 6 cont. Selected studies on BoNT/A in treatment of upper limb spasticity

\begin{tabular}{|c|c|c|c|c|c|}
\hline References & Study design & $\begin{array}{l}\text { Patient characteristics } \\
\text { and outcome measures }\end{array}$ & $\begin{array}{l}\text { BoNT-A } \\
\text { and dose (U) }\end{array}$ & $\begin{array}{l}\text { Muscles injected/ } \\
\text { /njection guide }\end{array}$ & $\begin{array}{l}\text { Efficacy outcome/ } \\
\text { /adverse events }\end{array}$ \\
\hline $\begin{array}{l}\text { Abo et al. } \\
2020 \text { [57] }\end{array}$ & $\begin{array}{l}\text { RCT, prospective, } \\
\text { multi-centre, } \\
\text { double-blind, } \\
\text { placebo-con- } \\
\text { trolled, dose } \\
\text { ranging }\end{array}$ & $\begin{array}{l}n=131 \\
\text { PS with MAS scores at least } 3 \\
\text { in elbow and at least } 2 \text { in wrist } \\
\text { or fingers; } \\
\text { MAS for elbow, wrist, fingers, } \\
\text { thumb. } \\
\text { DAS in principal target do- } \\
\text { main (limb position, dressing, } \\
\text { hygiene, pain), CGI }\end{array}$ & $\begin{array}{l}\text { ONA-BoNT/A } 400 \mathrm{U} \\
\text { ( } 240 \mathrm{U} \text { in forearm } \\
\text { and } 160 \mathrm{U} \text { in elbow } \\
\text { flexors) } \\
\text { or } \\
\text { single treatment of } \\
\text { ONA-BoNT/A ( } 240 \mathrm{U} \\
\text { in forearm and } \\
\text { placebo in elbow } \\
\text { flexors) }\end{array}$ & $\begin{array}{l}\text { FCR, FCU, FDP, FDS, } \\
\text { FP, ADDP } \\
\text { additional injection: } \\
\text { BB, B, BR; } \\
\text { anatomical land- } \\
\text { marks }\end{array}$ & $\begin{array}{l}\text { Forearm MAS reduction in } \\
\text { ONA-BoNT/A and forearm only } \\
\text { group; elbow flexors greater MAS } \\
\text { reduction. } \\
\text { Improvement in DAS, } \\
\text { Investigator's CGI - similar in both } \\
\text { groups }\end{array}$ \\
\hline $\begin{array}{l}\text { Lindsay et al. } \\
2020 \text { [58] }\end{array}$ & $\begin{array}{l}\text { RCT, prospective, } \\
\text { single-centre, } \\
\text { double-blind, } \\
\text { placebo-con- } \\
\text { trolled }\end{array}$ & $\begin{array}{l}\mathrm{n}=93 \\
\text { PS after } 6 \text { weeks, with spastici- } \\
\text { ty and ARAT grasp score } \leq 2 \text {; } \\
\text { EMG, Tardieu scale, PROM, } \\
\text { ARAT }\end{array}$ & $\begin{array}{l}\text { ONA-BoNT/A } 160 \text { U } \\
\text { or } \\
\text { placebo }\end{array}$ & $\begin{array}{l}\text { B, BB, FDS, FDP, FCU, } \\
\text { FCR } \\
\text { ES or US guidance }\end{array}$ & $\begin{array}{l}\text { Spasticity reduction in ONA-BoNT/A } \\
\text { group with significant difference } \\
\text { between weeks } 2 \text { and } 12 \text { (elbow) } \\
\text { and weeks } 2 \text { and } 6 \text { (wrist); slower } \\
\text { development of contracture, PROM } \\
\text { higher in E group. No differences in } \\
\text { ARAT between groups }\end{array}$ \\
\hline
\end{tabular}

RCT — randomised controlled trial; PS - post stroke; MAS — modified Ashworth scale; PROM — passive range of motion; BI — Barthel Index, Goal Attainment Scaling; BB - biceps brachii; FCR — flexor carpi radialis; FCU - flexor carpi ulnaris; FDS - flexor digitorum superficialis; FDP - flexor digitorum profundus; AE - adverse event; AS - Ashworth Scale; DAS - Disability Assessment Scale; FPL — flexor pollicis longus; ADDP - adductor pollicis; NA - not applicable; FIM - functional independence measure; SF-36 - 36-Item Short-Form Health Survey; E1/E2/E3 - experimental groups; EMG - electromyography; pts - patients; AQoL — Assessment of Quality of Life scale; VAS — visual analogue scale; HADs — Hospital Anxiety and Depression Rating Scale; MMAS - Modified Motor Assessment Scale; BR - brachialis; pts - patients; $A Q 0 L$ - Assessment of Quality of Life scale; VAS - visual analogue scale, $\mathrm{HADs}$ - Hospital Anxiety and Depression Rating Scale; MMAS - Modified Motor Assessment Scale; BR - brachialis;
$\mathrm{B}-\mathrm{R}$ - brachio-radialis; TRIC - triceps; FPB - flexor pollicis brevis; ES - electrostimulation; OPP - opponens pollicis; PT — pronator teres; PQ - pronator quadratus; CGI - Clinical Global Impression; ADL — activities of daily living; WMFT — Wolf Motor Function Test; AROM — active range of motion; SIS — Stroke Impact Scale; PECM — pectoralis major; TM - teres major; mRS - modified Rankin Score; PTBI post traumatic brain injury; PGA — Physician Global Assessment; PTMG — primary target muscle group; UL — upper limb; ARAT — Action Research Arm Test; US — ultrasound

(m. rectus femoris, m. hamstrings, $m$. adductor magnus, $m$. adductor longus, $m$. adductor brevis, $m$. gracillis, $m$. gluteus maximus).

There is no recommendation for treatment of focal lower limb spasticity in the INCO-BoNT/A SPC.

The only study that provides findings on the conversion ratio (ABO-BoNT/A vs. ONA-BoNT/A) for lower limb muscles was performed in a group of healthy volunteers [61]. A double-blind, randomised, dose-escalation study assessed the electrophysiological response of extensor digitorum brevis muscle after BoNT/A injection. Dose response curves for 1-20 U of ABO-BoNT/A and ONA-BoNT/A showed an initial rapid decrease in compound muscle action potential (CMAP) at doses ranging from 1 to $6 \mathrm{U}$, although this decrease was lower at higher concentrations. Statistical modelling predicted that, at the lower concentration, a mean decrease in CMAP to $73 \%$ of baseline value would be achieved with $1 \mathrm{U}$ of ONABoNT/A. For a comparable effect, $1.57 \mathrm{U}$ of ABO-BoNT/A would be required. The authors concluded that a dose ratio equivalence of $3: 1$, tested in control clinical trials, would be within the statistical error limits of the model [61].

There are no studies comparing head-to-head the effectiveness and safety profile of different BoNT/A formulations in the treatment of adult LLS. But there have been nine randomised controlled trials (RCTs) evaluating the effectiveness of different preparations of BoNT/A in reducing ankle plantar-flexor spasticity [62-70]. These may indirectly show what doses were used to achieve statistically meaningful effects. However, seeking a conversion ratio based on such a comparison is inappropriate. Detailed descriptions of pivotal studies of both ONA- and ABO-BoNT/A in LLS are set out in Table 7.
The doses tested were established at the beginning of most studies, and ranged from 500 up to 1,500 $\mathrm{U}$ of $\mathrm{ABO}$ - and up to $400 \mathrm{U}$ of ONA-BoNT/A. Adverse events in treatment groups were usually more frequent when compared to a placebo, but either not clinically relevant or not medication-related. In one study, in approximately $20 \%$ of patients a significant reduction of muscle tone was noticed up to week 16 [63].

There has been no RCT evaluating INCO-BoNT/A in the treatment of LLS. An open-label study assessed 71 patients with stroke-related ankle plantar-flexor muscles spasticity treated with a single injection of INCO-BoNT/A at a maximum total dose of $180 \mathrm{U}$ for a change in MAS, frequency of daily spasm, and passive ankle dorsiflexion grade of motion. A significant reduction in MAS and improvement in other evaluated parameters at 30 days was reported (MAS t0 $=3.9 \pm 0.6$; $\mathrm{t} 1=2.5 \pm 1.0 ; \mathrm{p}=0.00)$ and also at 90 days (MAS t0 $=3.9 \pm 0.6$; $\mathrm{t} 1=3.0 \pm 1.0 ; \mathrm{p}=0.00)$ of follow-up. During the study, only $11 \%$ of patients experienced treatment-emergent, but reversible, adverse events [71].

It is difficult to weigh up the similarities and differences between available studies concerning different BoNT/A medications efficacy in the treatment of LLS in adults. These studies shared no common endpoints except for MAS of the ankle plantar flexor muscles [62-70]. All available studies confirm a beneficial effect in reducing MAS score in patients treated with BoNT/A. The scheme of BoNT/A injection differed between the studies with hamstrings being injected, if needed, in the Wein study [62]. In all studies, except for that by Pittock et al. [64], selected muscles were targeted using ES, EMG or US guidance. 
Table 7. Selected studies on BoNT/A in treatment of spasticity of ankle plantar flexor muscles

\begin{tabular}{|c|c|c|c|c|c|}
\hline References & Study design & $\begin{array}{l}\text { Patient characteristics } \\
\text { and outcome measures }\end{array}$ & $\begin{array}{l}\text { BoNT/A } \\
\text { and dose (U) }\end{array}$ & $\begin{array}{l}\text { Muscles injected/ } \\
\text { injection guide }\end{array}$ & $\begin{array}{l}\text { Efficacy outcome/ adverse } \\
\text { events }\end{array}$ \\
\hline $\begin{array}{l}\text { Pittock et al. } \\
2003 \text { [64] }\end{array}$ & $\begin{array}{l}\text { RCT, dou- } \\
\text { ble-blind, } \\
\text { dose-ranging, } \\
\text { placebo-con- } \\
\text { trolled }\end{array}$ & $\begin{array}{l}\mathrm{n}=234 \\
\text { MAS for ankle plantar } \\
\text { flexor, } 2 \text { MWT, step length, } \\
\text { stepping rate, RMA, PROM } \\
\text { of ankle, subjective assess- } \\
\text { ment of pain in knee, leg, } \\
\text { ankle, foot }\end{array}$ & $\begin{array}{l}3 \text { doses of abo- } \\
\text { BoNT/A: } \\
\text { 1st group (59 pts): } \\
500 \mathrm{U} \text {; } \\
\text { 2nd group ( } 60 \mathrm{pts}): \\
\text { 1,000 U; } \\
\text { 3rd group ( } 60 \mathrm{pts}): \\
1,500 \mathrm{U}\end{array}$ & $\begin{array}{l}\mathrm{GM}, \mathrm{GL}, \mathrm{SOL} \text {; anatom- } \\
\text { ical landmarks }\end{array}$ & $\begin{array}{l}\text { MAS score reduction throughout } \\
\text { study period in all groups; greatest } \\
\text { improvements in MAS score in } 3^{\text {rd }} \\
\text { group; } \\
\text { AEs: } 130 \text { adverse events recorded } \\
\text { by } 68 \text { out of } 234 \text { pts ( } 10 \text { pts } \\
\text { receiving abo-BoNT/A considered } \\
\text { severe AE and related to treatment: } \\
\text { pharyngitis, dysphagia, headache, } \\
\text { somnolence, dizziness, pain, asthe- } \\
\text { nia, abnormal gait) }\end{array}$ \\
\hline $\begin{array}{l}\text { Mancini et al. } \\
2005 \text { [68] }\end{array}$ & $\begin{array}{l}\text { RCT, dou- } \\
\text { ble-blind, } \\
\text { dose-ranging }\end{array}$ & $\begin{array}{l}n=45 \\
\text { MAS and MRC of spastic } \\
\text { foot, gait assessment, } \\
\text { Achilles tendon clonus, VAS } \\
\text { for gait function and pain }\end{array}$ & $\begin{array}{l}3 \text { doses of ONA- } \\
\text { BoNT/A: } \\
\text { 1st group (15pts): } \\
167 \mathrm{U} ; \\
\text { 2nd group (15pts): } \\
322 \mathrm{U} ; \\
\text { 3rd group (15pts): } \\
540 \mathrm{U}\end{array}$ & $\begin{array}{l}\text { GM, GL, TP, SOL; EMG } \\
\text { guidance }\end{array}$ & $\begin{array}{l}\text { Reduction of MAS score in all } 3 \\
\text { groups; } \\
\text { AEs: in 3rd group (prolonged } \\
\text { weakness of treated limb, flu-like } \\
\text { syndrome, oedema of injected } \\
\text { limb) }\end{array}$ \\
\hline $\begin{array}{l}\text { Kaji et al. } \\
2010 \text { [65] }\end{array}$ & $\begin{array}{l}\text { RCT, dou- } \\
\text { ble-blind, place- } \\
\text { bo-controlled, } \\
\text { single cycle }\end{array}$ & $\begin{array}{l}n=120 \\
\text { MAS for ankle plantar- } \\
\text { flexor muscles, gait pattern, } \\
\text { speed of gait, CGI }\end{array}$ & $\begin{array}{l}300 \text { U ONA-BoNT/A; } \\
\text { placebo }\end{array}$ & $\begin{array}{l}\text { SOL, GM, GL, TP; EMG } \\
\text { or ES guidance }\end{array}$ & $\begin{array}{l}\text { Significant improvement in MAS } \\
\text { and CGI (investigator). } \\
\text { No significant differences in gait } \\
\text { patterns and speed; } \\
\text { AEs: } 7 \text { pts (myalgia) }\end{array}$ \\
\hline $\begin{array}{l}\text { Gracies et al. } \\
2017 \text { [63] }\end{array}$ & $\begin{array}{l}\text { Single-cycle } \\
\text { multicentre, RCT, } \\
\text { double-blind, } \\
\text { placebo-con- } \\
\text { trolled }\end{array}$ & $\begin{array}{l}\mathrm{n}=331 \\
\text { MAS for ankle plantar-flexor } \\
\text { muscles, comfortable bare- } \\
\text { foot walking speed, PGA }\end{array}$ & $\begin{array}{l}1,000 \mathrm{U} \text { and } 1,500 \mathrm{U} \\
\text { of } \mathrm{ABO}-\mathrm{BoNT} / \mathrm{A} ; \\
\text { placebo }\end{array}$ & $\begin{array}{l}\text { SOL, GM, GL; ES } \\
\text { guidance }\end{array}$ & $\begin{array}{l}\text { Consistent efficacy in MAS for } \\
1,500 \mathrm{U} \\
\text { AEs: falls, pain in extremities, mus- } \\
\text { cle weakness }\end{array}$ \\
\hline $\begin{array}{l}\text { Wein et al. } \\
2018 \text { [62] }\end{array}$ & $\begin{array}{l}\text { Multicentre, RCT, } \\
\text { double-blind, } \\
\text { placebo-con- } \\
\text { trolled }\end{array}$ & $\begin{array}{l}\mathrm{n}=447 \\
\text { MAS for ankle plantar- } \\
\text { flexor muscles, CGI, GAS, } \\
\text { pain scale }\end{array}$ & $\begin{array}{l}\text { ONA-BoNT/A } \\
(\leq 400 \text { U); placebo }\end{array}$ & $\begin{array}{l}\text { SOL, GM, GL, TP, oth- } \\
\text { ers (FDL, FDB, FHL, } \\
\text { EH, RF)* } \\
\text { EMG and US guid- } \\
\text { ance }\end{array}$ & $\begin{array}{l}\text { Significantly improved MAS, CGI, } \\
\text { and GAS scores vs. placebo } \\
\text { AE: } 39 \text { pts (injection site pain, injec- } \\
\text { tion site mass, muscular weakness) }\end{array}$ \\
\hline
\end{tabular}

*maximum permitted dose in optional muscles, to a total additional dose of $\leq 100 \mathrm{U}$ during double-blind phase; SOL — soleus; GM — gastrocnemius medial head; GL — gastrocnemius lateral head; TP — tibialis posterior; FDL - flexor digitorum longus; FDB - flexor digitorum brevis; FHL - flexor hallucis longus; EH — extensor hallucis; RF - rectus femoris; PGA - physician global assessment; $2 \mathrm{MWT}$ - 2-min walking test; RMA — Rivermead Motor Assessment; PADFM — passive ankle dorsiflexion grade of motion; SFS — spasm frequency scale; AE — investigator-determined treatment-related adverse events

The presented studies reported that amounts of ONA-BoNT/A (range 300-400 U), ABO-BoNT/A (500-1,500 U) and $180 \mathrm{U}$ of INCO-BoNT/A were effective and safe.

\section{Conclusions}

- The comparative study was performed in lower limb muscles of healthy volunteers without spasticity, using an electrophysiological method of assessment

- It is challenging to establish the comparative potencies and the equivalence ratio between $\mathrm{ABO}-\mathrm{BoNT} / \mathrm{A}$, INCO-BoNT/A, and ONA-BoNT/A in the treatment of LLS limb spasticity, as doses were adapted in almost all studies and based on diverse protocols, with no head-to-head designs.

\section{Recommendations and guidelines}

In 2009, the US Food and Drug Administration (FDA) established non-proprietary names for the BoNT/A preparations manufactured by Allergan (onabotulinumtoxin A), Ipsen (abobotulinumtoxin A), and Merz (incobotulinumtoxin A). This decision reflected the opinion that individual BoNT/A brands should not be treated as interchangeable due to different purification methods and differences in the final product of purification, different ways of assessing activity, as well as different units in which activity is expressed [72, 73]. Non-proprietary names were also intended to prevent possible errors resulting from the use of the same abbreviations for BoNT/A products supplied to the market by different manufacturers. 


\section{Dystonia}

Practice guidelines for the BoNT/A treatment of movement disorders were published for the first time by the American Academy of Neurology (AAN) in 2008 [74]. This document summarised the available studies on the use of BoNT/A, /B in the treatment of BS, CD, HFS, limb and laryngeal dystonia, tics and essential tremor.

Botulinum toxin type-A was assigned a level A recommendation only for the treatment of $\mathrm{CD}$. This was based on the results of seven Class I studies (two with ONA-BoNT/A, two with $\mathrm{ABO}-\mathrm{BoNT} / \mathrm{A}$, and three with type B toxin). Level $B$ recommendation was assigned for the treatment of $B S$ (two Class II studies with Botox), focal upper limb dystonia (one Class I study with ABO-BoNT/A and three Class II studies with ONA-BoNT/A), laryngeal dystonia (one ONA-BoNT/A Class I study) and essential tremor (two Class II studies with ONA-BoNT/A).

The guidelines on the diagnosis and treatment of primary dystonias published by the European Federation of Neurological Societies (EFNS) in 2011 were less detailed, and all marketed formulations of BoNT/A were considered as the same class [75]. The main recommendations considered BoNT/A as a first-line treatment for primary cranial (excluding oromandibular), writer's cramp and $\mathrm{CD}$ (level A) [75].

Updated AAN practice guidelines for the BoNT/A treatment of BS, CD, adult spasticity and headache were published in 2016 (76). The authors noted that there are important differences from a clinical point of view between BoNT/A preparations, including potency and duration of action. Therefore, in the updated document, the efficacy and safety of each preparation was evaluated separately. This approach resulted in a reduction in the level of recommendation in individual indications. Only ABO-BoNT/A obtained a level A recommendation for treatment of $\mathrm{CD}$ (two Class I studies). Both ONA-BoNT/A (one Class I and one Class II study) and INCO-BoNT/A (one Class I study) were assigned level B. Moreover, the AAN noted that the results of one (Class I) comparative study showed that $\mathrm{ABO}$ - and ONA-BoNT/A are probably equally effective in treating $\mathrm{CD}$. ONA-BoNT/A (two Class II studies) and INCO-BoNT/A (one Class I study) were considered to be probably effective (Level $\mathrm{B}$ ) in BS, and $\mathrm{ABO}-\mathrm{BoNT} / \mathrm{A}$ was assigned a level $\mathrm{C}$ recommendation (one Class II study) in this indication. According to comparative (two Class I and one Class II) studies, ONA- and INCO-BoNT/A are equivalent in efficacy in treating BS, while $\mathrm{ABO}$ - and ONA-BoNT/A are possibly equivalent (one Class II study) [76].

\section{Spasticity in adults}

The first report of the Therapeutics and Technology Assessment Subcommittee of the AAN on the treatment of spasticity with BoNT/A was published in 2008 [74]. The conclusion was that BoNT/A is effective in the treatment of ULS in adults (level A). This was based on six Class I studies including $\mathrm{ABO}-\mathrm{BoNT} / \mathrm{A}$ and four Class I studies with the use of ONA-BoNT/A. The therapy was also considered effective in LLS (two Class I studies of ABO- and one Class I study of Ona-BoNT/A). Botulinum toxin injections were found to be effective for reducing muscle tone and increasing the range of motion in affected limbs, and probably effective in improving active function (level B, one Class I study of ABO-BoNT/A). There were no specific recommendations regarding the differences between products [74].

A European Consensus on the use of BoNT/A in spasticity resulting from the collaboration of 28 experts from 16 countries was published in 2009 [77]. The authors based their conclusions on the results of 21 randomised clinical trials (12 in upper limbs, seven in lower limbs and two in mixed upper and lower limbs) as well as on the results of one meta-analysis. At that time, only ONA- and ABO-BoNT/A data were available, and the maximum recommended single doses for these preparations were $600 \mathrm{U}$ and $1,500 \mathrm{U}$, respectively.

The main conclusion was that BoNT/A significantly reduced muscle tone and improved passive function in adult subjects with spasticity. The authors also attempted to take a position on the issues that were not answered directly by the results of controlled studies in spasticity. The unwanted spread of toxin from the site of injection is a potential cause of side effects related to weakness of adjacent and distant muscles. From a clinical point of view, the low migration potential is a desirable feature that reduces the risk of side effects, something especially important in spasticity where high doses of drugs are used. ABO- and ONA-BoNT/A migration potentials were not compared in spasticity studies. However, the results of studies in hyperhidrosis and CD showed that ONA- administration was associated with less migration than in the case of $\mathrm{ABO}-\mathrm{BoNT} / \mathrm{A}$. The contributors to the Consensus clearly expressed their negative opinion on the conversion in clinical practice of doses of BoNT/A preparations supplied by various manufacturers [77]. This was best expressed by Aoki et al.: "It is important that clinicians are familiar with the characteristics and dosages of each preparation they use, and do not try to convert or extrapolate from one preparation to another." [78].

The updated 2016 AAN practice guidelines concluded that all three commercially available BoNT/A formulations are effective in ULS (level A). The data confirmed that they are effective in reducing muscle tension and improving passive function. $\mathrm{ABO}-$ and ONA-BoNT/A were also recommended (level A) for the treatment of LLS. In the case of INCO-BoNT/A, data on its effectiveness in lower limb spasticity was considered insufficient [79].

\section{Conclusions}

- No published recommendations have suggested any conversion ratios between dosages of specific BoNT/A formulations. Even so, when suggesting that two preparations are equal in terms of efficacy, this means that a significant 
treatment effect has been achieved in a Class I or II study for a specific indication

- It is impossible to compare the specific doses used and translate them into the ratio between them.

\section{Summary}

Having reviewed all studies using BoNT/A different preparations for CD, BS, HFS and ULS and LLS, despite there being a number of direct comparative studies, there is still no definitive evidence on clear ratios between preparations.

We therefore conclude that despite the similar molecular mechanisms of different BoNT/A preparations, in terms of basic and clinical studies they should be considered to be distinct medications. All should be used in accordance with their individual SPC. The ongoing clinical trials with new (DAXI or PRA-BoNT/A) formulations will make this discussion even more difficult and complex.

We have not mentioned so far differences in the potency of neutralising antibodies (NAB) formation. Preparations may differ in terms of this potency, and switching the treatment from one to another preparation, as suggested by Hefter et al., may be helpful. During the 48-week period of INCO-BoNT/A treatment, NAB titres in patients with previously ineffective treatment with the use of other preparations decreased in $32.2 \%$, did not change in $45.2 \%$, and increased in only $22.6 \%$ of patients. Thus, repeated treatment with a low dose of $200 \mathrm{U}$ INCO-BoNT/A over 48 weeks provided a beneficial clinical long-term effect [80]. This gives rise to a new perspective regarding the problem of switching between these medications in clinical practice.

\section{References}

1. Sławek J, Car H, Bonikowski M, et al. Are botulinum toxin type A preparations really the same medication? A comparison of three botulinum toxin A for variations in labelled neurological indications. Neurol Neurochir Pol. 2010; 44(1): 43-64, doi: 10.1016/s00283843(14)60406-0, indexed in Pubmed: 20358485.

2. Ferrari A, Manca M, Tugnoli $V$, et al. Pharmacological differences and clinical implications of various botulinum toxin preparations: a critical appraisal. Funct Neurol. 2018; 33(1): 7-18, doi: 10.11138/ fneur/2018.33.1.007, indexed in Pubmed: 29633692.

3. Car H, Bogucki A, et al. Botulinum toxin type-A preparations are not the same medications - basic science (Part 1) . Neurol Neurochir Pol. 2021; 55 (2): 133-140, doi: 10.5603/PJNNS.a2021.0027, indexed in Pubmed: 33797747.

4. Allergan, Ltd. ВОТОХ ${ }^{\circledR} 100$ U. Summary of product characteristics [webpage on the Internet]. Surrey, UK: Datapharm Communications Ltd; 2013. http://www.medicines.org.uk/emc/medicine/112 (October 8, 2020).

5. Dysport $\circledast$ (abobotulinumtoxinA) [prescribing information]. Boulogne-Billancourt: IpsenBiopharm Ltd; 2012. (October 8, 2020).

6. XEOMIN (50/100/200) units powder for solution for injection summary of product characteristics. https://www.medicines.ie/ medicines/xeomin-50-100-200-units-powder-for-solution-for-injection-34858/spc\#! (November 2019).
7. Marion MH, Sheehy M, Sangla S, et al. Dose standardisation of botulinum toxin. J Neurol Neurosurg Psychiatry. 1995; 59(1): 102-103, doi: 10.1136/jnnp.59.1.102, indexed in Pubmed: 7608697.

8. Sampaio C, Ferreira JJ, Simões F, et al. DYSBOT: a single-blind, randomized parallel study to determine whether any differences can be detected in the efficacy and tolerability of two formulations of botulinum toxin type A-Dysport and Botox-assuming a ratio of 4:1. Mov Disord. 1997; 12(6): 10131018, doi: 10.1002/mds.870120627, indexed in Pubmed: 9399229.

9. Nüssgens Z, Roggenkämper P. Comparison of two botulinum-toxin preparations in the treatment of essential blepharospasm. Graefes Arch Clin Exp Ophthalmol. 1997; 235(4): 197-199, doi: 10.1007/ BF00941758, indexed in Pubmed: 9143885.

10. Bihari K. Safety, effectiveness, and duration of effect of BOTOX after switching from Dysport for blepharospasm, cervical dystonia, and hemifacial spasm dystonia, and hemifacial spasm. Curr Med Res Opin. 2005; 21(3): 433-438, doi: 10.1185/030079905X36396, indexed in Pubmed: 15811212.

11. Marchetti A, Magar R, Findley L, et al. Retrospective evaluation of the dose of Dysport and BOTOX in the management of cervical dystonia and blepharospasm: the REAL DOSE study. Mov Disord. 2005; 20(8): 937-944, doi: 10.1002/mds.20468, indexed in Pubmed: 15810022.

12. Bentivoglio AR, lalongo $T$, Bove $F$, et al. Retrospective evaluation of the dose equivalence of Botox $(\AA)$ and Dysport $(\Theta)$ in the management of blepharospasm and hemifacial spasm: a novel paradigm for a never ending story. Neurol Sci. 2012; 33(2): 261-267, doi: 10.1007/ s10072-011-0672-7, indexed in Pubmed: 21710123.

13. Dressler D. Routine use of XeominÂ̊ in patients previously treated with BotoxÂ®: long term results. European Journal of Neurology. 2009; 16: 2-5, doi: 10.1111/j.1468-1331.2009.02877.x.

14. Roggenkämper P, Jost WH, Bihari K, et al. NT 201 Blepharospasm Study Team. Efficacy and safety of a new Botulinum Toxin Type A free of complexing proteins in the treatment of blepharospasm. J Neural Transm (Vienna). 2006; 113(3): 303-312, doi: 10.1007/s00702005-0323-3, indexed in Pubmed: 15959841.

15. Saad J, Gourdeau A. A direct comparison of onabotulinumtoxina (Botox) and IncobotulinumtoxinA (Xeomin) in the treatment of benign essential blepharospasm: a split-face technique. J Neuroophthalmol. 2014; 34(3): 233-236, doi: 10.1097/WN0.0000000000000110, indexed in Pubmed: 24739994.

16. Wabbels B, Reichel G, Fulford-Smith A, et al. Double-blind, randomised, parallel group pilot study comparing two botulinum toxin type A products for the treatment of blepharospasm. J Neural Transm (Vienna). 2011; 118(2): 233-239, doi: 10.1007/s00702-010-0529-x, indexed in Pubmed: 21161715.

17. Chundury RV, Couch SM, Holds JB, et al. Comparison of preferences between onabotulinumtoxinA (Botox) and incobotulinumtoxinA (Xeomin) in the treatment of benign essential blepharospasm. Ophthalmic Plast Reconstr Surg. 2013; 29(3): 205-207, doi: 10.1097/ IOP.0b013e31828de0d6, indexed in Pubmed: 23552607.

18. Juarez H, Salvador S, Hernandez L, et al. et al.. Cost benefit assessment of two forms of botulinum toxin type $A$ in different pathologies. Ann Neurol. 2011; 70: S21.

19. Grosset DG, Tyrrell EG, Grosset KA. Switch from abobotulinumtoxinA (Dysport $\circledast$ ) to incobotulinumtoxinA (Xeomin $®$ ) botulinum toxin formulation: a review of 257 cases. J Rehabil Med. 2015; 47(2): 183-186, doi: 10.2340/16501977-1895, indexed in Pubmed: 25325305.

20. Kollewe K, Mohammadi B, Köhler S, et al. Blepharospasm: long-term treatment with either Botox $\AA$, Xeomin $\AA$ or Dysport $\AA$. J Neural Transm (Vienna). 2015; 122(3): 427-431, doi: 10.1007/s00702-014-1278-z, indexed in Pubmed: 25059456. 
21. Jankovic J, Orman J. Botulinum A toxin for cranial-cervical dystonia: a double-blind, placebo-controlled study. Neurology. 1987; 37(4): 616-623, doi: 10.1212/wnl.37.4.616, indexed in Pubmed: 3561773.

22. Yoshimura DM, Aminoff MJ, Tami TA, et al. Treatment of hemifacial spasm with botulinum toxin. Muscle Nerve. 1992; 15(9): 1045-1049, doi: 10.1002/mus.880150909, indexed in Pubmed: 1518513.

23. Girlanda P, Quartarone A, Sinicropi S, et al. Unilateral injection of botulinum toxin in blepharospasm: single fiber electromyography and blink reflex study. Mov Disord. 1996; 11(1): 27-31, doi: 10.1002/ mds.870110107, indexed in Pubmed: 8771064.

24. Truong D, Comella C, Fernandez HH, et al. Dysport Benign Essential Blepharospasm Study Group. Efficacy and safety of purified botulinum toxin type $A$ (Dysport) for the treatment of benign essential blepharospasm: a randomized, placebo-controlled, phase II trial. Parkinsonism Relat Disord. 2008; 14(5): 407-414, doi: 10.1016/j. parkreldis.2007.11.003, indexed in Pubmed: 18325821.

25. Jankovic J, Comella C, Hanschmann A, et al. Efficacy and safety of incobotulinumtoxinA (NT 201, Xeomin) in the treatment of blepharospasm-a randomized trial. Mov Disord. 2011; 26(8): 1521-1528, doi: 10.1002/mds.23658, indexed in Pubmed: 21520284.

26. Odergren $\mathrm{T}$, Hjaltason $\mathrm{H}$, Kaakkola $\mathrm{S}$, et al. A double blind, randomised, parallel group study to investigate the dose equivalence of Dysport and Botox in the treatment of cervical dystonia. J Neurol Neurosurg Psychiatry. 1998; 64(1): 6-12, doi: 10.1136/jnnp.64.1.6, indexed in Pubmed: 9436720.

27. Ranoux D, Gury C, Fondarai J, et al. Respective potencies of Botox and Dysport: a double blind, randomised, crossover study in cervical dystonia. J Neurol Neurosurg Psychiatry. 2002; 72(4): 459-462, doi: 10.1136/jnnp.72.4.459, indexed in Pubmed: 11909903.

28. Rystedt A, Zetterberg L, Burman J, et al. A Comparison of Botox 100 $\mathrm{U} / \mathrm{mL}$ and Dysport $100 \mathrm{U} / \mathrm{mL}$ Using Dose Conversion Ratio 1: 3 and 1: 1.7 in the Treatment of Cervical Dystonia: A Double-Blind, Randomized, Crossover Trial. Clin Neuropharmacol. 2015; 38(5): 170176, doi: 10.1097/WNF.0000000000000101, indexed in Pubmed: 26366966.

29. Yun JiY, Kim JW, Kim HT, et al. Dysport and Botox at a ratio of 2.5:1 units in cervical dystonia: a double-blind, randomized study. Mov Disord. 2015; 30(2): 206-213, doi: 10.1002/mds.26085, indexed in Pubmed: 25476727.

30. Benecke R, Jost WH, Kanovsky $P$, et al. A new botulinum toxin type A free of complexing proteins for treatment of cervical dystonia. Neurology. 2005; 64(11): 1949-1951, doi: 10.1212/01. WNL.0000163767.99354.C3, indexed in Pubmed: 15955951.

31. Lorentz IT, Subramaniam SS, Yiannikas C. Treatment of idiopathic spasmodic torticollis with botulinum toxin A: a double-blind study on twenty-three patients. Mov Disord. 1991; 6(2): 145-150, doi: 10.1002/mds.870060210, indexed in Pubmed: 2057005.

32. Moore AP, Blumhardt LD. A double blind trial of botulinum toxin „A” in torticollis, with one year follow up. J Neurol Neurosurg Psychiatry. 1991; 54(9): 813-816, doi: 10.1136/jnnp.54.9.813, indexed in Pubmed: 1955900.

33. Lu CS, Chen RS, Tsai CH. Double-blind, placebo-controlled study of botulinum toxin injections in the treatment of cervical dystonia. J Formos Med Assoc. 1995; 94(4): 189-192, indexed in Pubmed: 7606182.

34. Poewe W, Deuschl G, Nebe A, et al. What is the optimal dose of botulinum toxin $A$ in the treatment of cervical dystonia? Results of a double blind, placebo controlled, dose ranging study using Dysport. German Dystonia Study Group. J Neurol Neurosurg Psychiatry. 1998; 64(1): 13-17, doi: 10.1136/jnnp.64.1.13, indexed in Pubmed: 9436721.
35. Truong D, Duane DD, Jankovic J, et al. Efficacy and safety of botulinum type A toxin (Dysport) in cervical dystonia: results of the first US randomized, double-blind, placebo-controlled study. Mov Disord. 2005; 20(7): 783-791, doi: 10.1002/mds.20403, indexed in Pubmed: 15736159.

36. Comella CL, Jankovic J, Truong DD, et al. U.S. XEOMIN Cervical Dystonia Study Group. Efficacy and safety of incobotulinumtoxinA (NT 201, XEOMIN ${ }^{\circ}$, botulinum neurotoxin type $A$, without accessory proteins) in patients with cervical dystonia. J Neurol Sci. 2011; 308(1-2): 103109, doi: 10.1016/j.jns.2011.05.041, indexed in Pubmed: 21764407.

37. Charles D, Brashear A, Hauser RA, et al. CD 140 Study Group. Efficacy, tolerability, and immunogenicity of onabotulinumtoxina in a randomized, double-blind, placebo-controlled trial for cervical dystonia. Clin Neuropharmacol. 2012; 35(5): 208-214, doi: 10.1097/ WNF.0b013e31826538c7, indexed in Pubmed: 22948497.

38. Evidente VG, Fernandez HH, LeDoux MS, et al. A randomized, double-blind study of repeated incobotulinumtoxinA (Xeomin(®)) in cervical dystonia. J Neural Transm (Vienna). 2013; 120(12): 1699-1707, doi: 10.1007/s00702-013-1048-3, indexed in Pubmed: 23779062.

39. Tyślerowicz M, Kiedrzyńska W, Adamkiewicz B, et al. Cervical dystonia - improving the effectiveness of botulinum toxin therapy. Neurol Neurochir Pol. 2020; 54(3): 232-242, doi: 10.5603/PJNNS.a2020.0021, indexed in Pubmed: 32285434.

40. Jost WH, Biering-Sørensen Bo, Drużdż A, et al. Preferred muscles in cervical dystonia. Neurol Neurochir Pol. 2020; 54(3): 277-279, doi: 10.5603/PJNNS.a2020.0022, indexed in Pubmed: 32227332.

41. Jost WH, Tatu L, Pandey S, et al. Frequency of different subtypes of cervical dystonia: a prospective multicenter study according to Col-Cap concept. J Neural Transm (Vienna). 2020; 127(1): 45-50, doi: 10.1007/s00702-019-02116-7, indexed in Pubmed: 31828512.

42. Jost WH, Drużdż A, Pandey S, et al. Dose per muscle in cervical dystonia: pooled data from seven movement disorder centres. Neurol Neurochir Pol. 2021 [Epub ahead of print], doi: 10.5603/PJNNS. a2021.0005, indexed in Pubmed: 33471347.

43. Schinwelski MJ, Sitek EJ, Wąż P, et al. Prevalence and predictors of post-stroke spasticity and its impact on daily living and quality of life. Neurol Neurochir Pol. 2019; 53(6): 449-457, doi: 10.5603/PJNNS. a2019.0067, indexed in Pubmed: 31845749.

44. Sarzyńska-Długosz I, Szczepańska-Szerej A, Drużdż A, et al. Real-world effectiveness of abobotulinumtoxinA (Dysport ${ }^{\circledR}$ ) in adults with upper limb spasticity in routine clinical practice: an observational study. Neurol Neurochir Pol. 2020; 54(1): 90-99, doi: 10.5603/PJNNS. a2020.0004, indexed in Pubmed: 31956971.

45. Bakheit AM, Pittock S, Moore AP, et al. A randomized, double-blind, placebo-controlled study of the efficacy and safety of botulinum toxin type $A$ in upper limb spasticity in patients with stroke. Eur J Neurol. 2001; 8(6): 559-565, doi: 10.1046/j.1468-1331.2001.00277.x, indexed in Pubmed: 11784339.

46. Brashear A, Gordon MF, Elovic E, et al. Botox Post-Stroke Spasticity Study Group. Intramuscular injection of botulinum toxin for the treatment of wrist and finger spasticity after a stroke. N Engl J Med. 2002; 347(6): 395-400, doi: 10.1056/NEJMoa011892, indexed in Pubmed: 12167681.

47. Childers MK, Brashear A, Jozefczyk P, et al. Dose-dependent response to intramuscular botulinum toxin type A for upper-limb spasticity in patients after a stroke. Arch Phys Med Rehabil. 2004; 85(7): 1063-1069, doi: 10.1016/j.apmr.2003.10.015, indexed in Pubmed: 15241751.

48. McCrory P, Turner-Stokes L, Baguley IJ, et al. Botulinum toxin A for treatment of upper limb spasticity following stroke: a multi-centre ran- 
domized placebo-controlled study of the effects on quality of life and other person-centred outcomes. J Rehabil Med. 2009; 41(7): 536544, doi: 10.2340/16501977-0366, indexed in Pubmed: 19543664.

49. Kanovský P, Slawek J, Denes Z, et al. Efficacy and safety of botulinum neurotoxin NT 201 in poststroke upper limb spasticity. Clin Neuropharmacol. 2009; 32(5): 259-265, doi: 10.1097/ WNF.0b013e3181b13308, indexed in Pubmed: 19644361.

50. Kaji R, Osako Y, Suyama K, et al. GSK1358820 Spasticity Study Group. Botulinum toxin type A in post-stroke upper limb spasticity. Curr Med Res Opin. 2010; 26(8): 1983-1992, doi: 10.1185/03007995.2010.497103, indexed in Pubmed: 20569068.

51. Wolf SL, Milton SB, Reiss A, et al. Further assessment to determine the additive effect of botulinum toxin type $A$ on an upper extremity exercise program to enhance function among individuals with chronic stroke but extensor capability. Arch Phys Med Rehabil. 2012; 93(4): 578-587, doi: 10.1016/j.apmr.2011.10.026, indexed in Pubmed: 22206630.

52. Marciniak CM, Harvey RL, Gagnon CM, et al. Does botulinum toxin type $A$ decrease pain and lessen disability in hemiplegic survivors of stroke with shoulder pain and spasticity?: a randomized, double-blind, placebo-controlled trial. Am J Phys Med Rehabil. 2012; 91(12): 1007-1019, doi: 10.1097/PHM.0b013e31826ecb02, indexed in Pubmed: 23064478.

53. Rosales RL, Kong KHe, Goh KJ, et al. Botulinum toxin injection for hypertonicity of the upper extremity within 12 weeks after stroke: a randomized controlled trial. Neurorehabil Neural Repair. 2012; 26(7): 812-821, doi: 10.1177/1545968311430824, indexed in Pubmed: 22371239.

54. Gracies JM, Brashear A, Jech R, et al. Safety and efficacy of abobotulinumtoxinA for hemiparesis in adults with upper limb spasticity after stroke or traumatic brain injury: a double-blind randomised controlled trial. The Lancet Neurology. 2015; 14(10): 992-1001, doi: 10.1016/ s1474-4422(15)00216-1.

55. Kaňovský P, Elovic EP, Munin MC, et al. Randomized, placebo-controlled trial of incobotulinumtoxina for upper-limb post-stroke spasticity. Muscle Nerve. 2016; 53(3): 415-421, doi: 10.1002/mus.24776, indexed in Pubmed: 26201835.

56. Rosales R, Balcaitiene J, Berard H, et al. Early AbobotulinumtoxinA (Dysport $\circledast$ ) in Post-Stroke Adult Upper Limb Spasticity: ONTIME Pilot Study. Toxins. 2018; 10(7): 253, doi: 10.3390/toxins10070253.

57. Abo M, Shigematsu T, Hara H, et al. Efficacy and Safety of OnabotulinumtoxinA 400 Units in Patients with Post-Stroke Upper Limb Spasticity: Final Report of a Randomized, Double-Blind, Placebo-Controlled Trial with an Open-Label Extension Phase. Toxins (Basel). 2020; 12(2), doi: 10.3390/toxins12020127, indexed in Pubmed: 32085529.

58. Lindsay C, Ispoglou S, Helliwell B, et al. Can the early use of botulinum toxin in post stroke spasticity reduce contracture development? A randomised controlled trial. Clin Rehabil. 2020 [Epub ahead of print]: 269215520963855, doi: 10.1177/0269215520963855, indexed in Pubmed: 33040610.

59. Intiso D, Simone V, Bartolo M, et al. High Dosage of Botulinum Toxin Type A in Adult Subjects with Spasticity Following Acquired Central Nervous System Damage: Where Are We at? Toxins (Basel). 2020; 12(5), doi: 10.3390/toxins12050315, indexed in Pubmed: 32397674.

60. Wissel J, Bensmail D, Ferreira JJ, et al. TOWER study investigators. Safety and efficacy of incobotulinumtoxinA doses up to $800 \mathrm{U}$ in limb spasticity: The TOWER study. Neurology. 2017; 88(14): 1321-
1328, doi: 10.1212/WNL.0000000000003789, indexed in Pubmed: 28283596.

61. Wohlfarth $\mathrm{K}$, Schwandt I, Wegner F, et al. Biological activity of two botulinum toxin type A complexes (Dysport and Botox) in volunteers: a double-blind, randomized, dose-ranging study. J Neurol. 2008; 255(12): 1932-1939, doi: 10.1007/s00415-008-0031-7, indexed in Pubmed: 18854916.

62. Wein T, Esquenazi A, Jost WH, et al. OnabotulinumtoxinA for the Treatment of Poststroke Distal Lower Limb Spasticity: A Randomized Trial. PM R. 2018; 10(7): 693-703, doi: 10.1016/j.pmrj.2017.12.006, indexed in Pubmed: 29330071.

63. Gracies JM, Esquenazi A, Brashear A, et al. International AbobotulinumtoxinA Adult Lower Limb Spasticity Study Group. Efficacy and safety of abobotulinumtoxinA in spastic lower limb: Randomized trial and extension. Neurology. 2017; 89(22): 2245-2253, doi: 10.1212/ WNL.0000000000004687, indexed in Pubmed: 29093068.

64. Pittock SJ, Moore AP, Hardiman O, et al. A double-blind randomised placebo-controlled evaluation of three doses of botulinum toxin type $\mathrm{A}$ (Dysport) in the treatment of spastic equinovarus deformity after stroke. Cerebrovasc Dis. 2003; 15(4): 289-300, doi: 10.1159/000069495, indexed in Pubmed: 12686794.

65. Kaji R, Osako Y, Suyama K, et al. GSK1358820 Spasticity Study Group. Botulinum toxin type A in post-stroke lower limb spasticity: a multicenter, double-blind, placebo-controlled trial. J Neurol. 2010; 257(8): 1330-1337, doi: 10.1007/s00415-010-5526-3, indexed in Pubmed: 20358216.

66. Burbaud P, Wiart L, Dubos JL, et al. A randomised, double blind, placebo controlled trial of botulinum toxin in the treatment of spastic foot in hemiparetic patients. J Neurol Neurosurg Psychiatry. 1996; 61(3): 265-269, doi: 10.1136/jnnp.61.3.265, indexed in Pubmed: 8795597.

67. Dunne JW, Gracies JM, Hayes M, et al. Multicentre Study Group. A prospective, multicentre, randomized, double-blind, placebo-controlled trial of onabotulinumtoxinA to treat plantarflexor/invertor overactivity after stroke. Clin Rehabil. 2012; 26(9): 787-797, doi: 10.1177/0269215511432016, indexed in Pubmed: 22308557.

68. Mancini F, Sandrini G, Moglia A, et al. A randomised, double-blind, dose-ranging study to evaluate efficacy and safety of three doses of botulinum toxin type $\mathrm{A}$ (Botox) for the treatment of spastic foot. Neurol Sci. 2005; 26(1): 26-31, doi: 10.1007/s10072-005-0378-9, indexed in Pubmed: 15877184.

69. Picelli A, Tamburin S, Bonetti P, et al. Botulinum toxin type A injection into the gastrocnemius muscle for spastic equinus in adults with stroke: a randomized controlled trial comparing manual needle placement, electrical stimulation and ultrasonography-guided injection techniques. Am J Phys Med Rehabil. 2012; 91(11): 957-964, doi: 10.1097/PHM.0b013e318269d7f3, indexed in Pubmed: 23085706.

70. Fietzek UM, Kossmehl P, Schelosky L, et al. Early botulinum toxin treatment for spastic pes equinovarus-a randomized double-blind placebo-controlled study. Eur J Neurol. 2014; 21(8): 1089-1095, doi: 10.1111/ene.12381, indexed in Pubmed: 24754350.

71. Santamato A, Micello MF, Panza F, et al. Safety and efficacy of incobotulinum toxin type A (NT 201-Xeomin) for the treatment of post-stroke lower limb spasticity: a prospective open-label study. Eur J Phys Rehabil Med. 2013; 49(4): 483-489, indexed in Pubmed: 23480980.

72. Brin MF, James C, Maltman J. Botulinum toxin type A products are not interchangeable: a review of the evidence. Biologics. 2014; 8: 227 241, doi: 10.2147/BTT.S65603, indexed in Pubmed: 25336912. 
73. Spiegel LL, Ostrem JL, Bledsoe IO. FDA Approvals and Consensus Guidelines for Botulinum Toxins in the Treatment of Dystonia. Toxins (Basel). 2020; 12(5), doi: 10.3390/toxins12050332, indexed in Pubmed: 32429600.

74. Simpson DM, Blitzer A, Brashear A, et al. So Y; Therapeutics and Technology Assessment Subcommittee of the American Academy of . Practice guideline update summary: Botulinum neurotoxin for the treatment of blepharospasm, cervical dystonia, adult spasticity, and headache: Report of the Guideline Development Subcommittee of the American Academy of . Neurology. 2008; 70: 1699-706.

75. Albanese A, Asmus F, Bhatia KP, et al. EFNS guidelines on diagnosis and treatment of primary dystonias. Eur J Neurol. 2011; 18(1): 5-18, doi: 10.1111/j.1468-1331.2010.03042.x, indexed in Pubmed: 20482602.

76. Simpson DM, Hallett M, Ashman EJ, et al. Practice guideline update summary: Botulinum neurotoxin for the treatment of blepharospasm, cervical dystonia, adult spasticity, and headache: Report of the Guideline Development Subcommittee of the American Academy of Neurology. Neurology. 2016; 86(19): 1818-1826, doi: 10.1212/ WNL.0000000000002560, indexed in Pubmed: 27164716.
77. Wissel J, Ward AB, Erztgaard P, et al. European consensus table on the use of botulinum toxin type A in adult spasticity. J Rehabil Med. 2009; 41(1): 13-25, doi: 10.2340/16501977-0303, indexed in Pubmed: 19197564.

78. Aoki KR, Ranoux D, Wissel J. Using translational medicine to understand clinical differences between botulinum toxin formulations. Eur J Neurol. 2006; 13 Suppl 4: 10-19, doi: 10.1111/j.1468-1331.2006.01649.x, indexed in Pubmed: 17112345.

79. Simpson DM, Gracies JM, Graham HK, et al. Therapeutics and Technology Assessment Subcommittee of the American Academy of Neurology. Assessment: Botulinum neurotoxin for the treatment of spasticity (an evidence-based review): report of the Therapeutics and Technology Assessment Subcommittee of the American Academy of Neurology. Neurology. 2008; 70(19): 1691-1698, doi: 10.1212/01. wnl.0000311391.00944.c4, indexed in Pubmed: 18458229.

80. Hefter H, Hartmann CJ, Kahlen U, et al. Clinical Improvement After Treatment With IncobotulinumtoxinA (XEOMIN $®$ ) in Patients With Cervical Dystonia Resistant to Botulinum Toxin Preparations Containing Complexing Proteins. Front Neurol. 2021; 12: 636590, doi: 10.3389/ fneur.2021.636590, indexed in Pubmed: 33633680. 